NBER WORKING PAPER SERIES

\title{
OFFICE VISITS PREVENTING EMERGENCY ROOM VISITS: EVIDENCE FROM THE FLINT WATER SWITCH
}

\author{
Shooshan Danagoulian \\ Daniel S. Grossman \\ David Slusky \\ Working Paper 27098 \\ http://www.nber.org/papers/w27098 \\ NATIONAL BUREAU OF ECONOMIC RESEARCH \\ 1050 Massachusetts Avenue \\ Cambridge, MA 02138 \\ May 2020
}

We thank Glenn Copeland of the Vital Records and Health Statistics Division and Matthew Schneider of the Medicaid Division of the Michigan Department of Health and Human Services for providing vital statistics data and facilitating receipt of Medicaid claims data linked to vital records. We gratefully acknowledge Phillip Levy and the Office of the Vice President of Research at Wayne State University for financial support. We also thank Antony Hsu, Michael Morrisey, Michael Kofoed, Valentina Duque, and Janet Currie, as well as conference participants at AHEC 2018, APPAM 2018, ASHEcon 2019, SEA 2019, NBER Summer Institute Children's Meetings 2019, and the NBER Health Care Meeting Winter 2019 and seminar participants at the Wayne State University Department of Economics and Center for Urban Responses to Environmental Stressors (CURES), Kansas State University, the University of Missouri-Kansas City, University of Michigan H2D2 and HSOP WIDTH, Indiana University, Cornell University, and San Diego State University for their helpful comments and suggestions. The views expressed herein are those of the authors and do not necessarily reflect the views of the National Bureau of Economic Research.

NBER working papers are circulated for discussion and comment purposes. They have not been peer-reviewed or been subject to the review by the NBER Board of Directors that accompanies official NBER publications.

(C) 2020 by Shooshan Danagoulian, Daniel S. Grossman, and David Slusky. All rights reserved. Short sections of text, not to exceed two paragraphs, may be quoted without explicit permission provided that full credit, including $(\odot)$ notice, is given to the source. 
Office Visits Preventing Emergency Room Visits: Evidence From the Flint Water Switch Shooshan Danagoulian, Daniel S. Grossman, and David Slusky

NBER Working Paper No. 27098

May 2020

JEL No. H75,I12,I18,J13,Q53,Q58

\begin{abstract}
$\underline{\text { ABSTRACT }}$
Emergency department visits are costly to providers and to patients. We use the Flint water crisis to test if an increase in office visits reduced avoidable emergency room visits. In September 2015, the city of Flint issued a lead advisory to its residents, alerting them of increased lead levels in their drinking water, resulting from the switch in water source from Lake Huron to the Flint River. Using Medicaid claims for 2013-2016, we find that this information shock increased the share of enrollees who had lead tests performed by 1.7 percentage points. Additionally, it increased office visits immediately following the information shock and led to a reduction of 4.9 preventable, non-emergent, and primary-care-treatable emergency room visits per 1000 eligible children $(8.2 \%)$. This decrease is present in shifts from emergency room visits to office visits across several common conditions. Our analysis suggest that children were more likely to receive care from the same clinic following lead tests and that establishing care reduced the likelihood parents would take their children to emergency rooms for conditions treatable in an office setting. Our results are potentially applicable to any situation in which individuals are induced to seek more care in an office visit setting.
\end{abstract}

Shooshan Danagoulian

656 W. Kirby St.

FAB 2095

Department of Economics

Detroit, MI 48202

fr4523@wayne.edu

Daniel S. Grossman

Business and Economics Building,

Box 6025

West Virginia University

Morgantown, WV 26506-6025

daniel.grossman@mail.wvu.edu

\author{
David Slusky \\ Department of Economics \\ University of Kansas \\ 1460 Jayhawk Boulevard \\ Lawrence, KS 66045 \\ and NBER \\ david.slusky@ku.edu
}




\section{Introduction}

Emergency departments (ED) are structured to diagnose and treat emergent conditions. As such, they may be an expensive alternative to primary care, for both the individual patient and the health care system. For those who lack access to primary care, however, they are the only option for healthcare (Grumbach, Keane, and Bindman, 1993). Many of these individuals are of low socio-economic status, and may be eligible for Medicaid. Those who are of low socio-economic status and seeking care for their children are almost certainly eligible for Medicaid. While multiple studies have demonstrated that expanded access to Medicaid increases emergency room usage paid for by Medicaid (Taubman et al., 2014; Nikpay et al., 2017), ${ }^{1}$ no study has been able to isolate the causal link between increased primary care and emergency room usage for those who are already eligible for Medicaid.

In this paper, we exploit a shock to primary care (measured by office visits) resulting from the Flint water contamination. On April 25, 2014, under state-appointed emergency management, the city of Flint switched its water source from Lake Huron to the Flint River. Water from the Flint River required treatment with strong disinfectants, which made it substantially more corrosive than the old water, leaching lead out of the existing delivery system into residential water (Masten et al., 2016). However, during the period in which water was sourced from the Flint River, local officials stressed that the city water was safe for consumption. Despite warnings and boil advisories in August and September 2014, and an EPA violation for exceeding organic chemical thresholds in December 2014, the water's high level of lead content was largely unconfirmed until September 2015. We use this last date as the start of the "treatment" period for our analysis,

\footnotetext{
${ }^{1}$ Some argue that ED visits increase, while others argue the increase is simply a shift in payer case mix (see, e.g., (Antwi et al., 2015; Finkelstein et al., 2016; Sommers et al., 2016; Sommers and Simon, 2017).
} 
because it represents the point at which city officials first issued a lead advisory in the face of a preponderance of evidence that Flint's drinking water was hazardous to its residents' health. ${ }^{2} \mathrm{We}$ treat this public lead advisory as an information shock.

The goals of this paper are twofold. First, we establish the extent to which knowledge of the water problems affected health care receipt. Then, we examine whether a change in primary care use causes a reduction in ED visits or a change in the distribution of those visits when they are treatable or preventable through primary care visits.

Whether, and to what extent, environmental disasters result in greater medical expenditures for affected populations remains an open empirical question. We determine the amount of medical services received by individuals in the affected areas before, during, and after a water change and a revelation of exposure to contaminated water. We find that Medicaid enrollees in Flint received lead tests at rates nearly 50 percent higher than enrollees from control cities following the information shock. The share of enrollees who had any office visit increased by 4 percent and 11 percent, respectively, in the first two quarters immediately following the shock, before decreasing in subsequent quarters. ED visits for preventable, non-emergent, and primary-care-treatable conditions (which we aggregate as "avoidable") decreased by 4.9 visits per 1000 eligible children per month $(8.2 \%)$. This decrease is present in shifts from ED visits to office visits across several common conditions. Flint residents who received lead tests were 15 percentage points (24\%) more likely to visit the clinic where they received their lead test in the 3 months that followed. This suggests that establishing care at a specific clinic or with a given physician is associated with a decreased likelihood of receiving care in an ED for a condition that is treatable in an office setting.

\footnotetext{
${ }^{2}$ We also estimate a flexible time form specification using two time periods - January to August 2015 and September 2015 to December 2016 - with similar findings. We present these results in Appendix H.
} 
In this study we contribute to several literatures, including those investigating lead exposure, the Flint water crisis, the unintended consequences of environmental or informational shocks on healthcare, and the substitutability of healthcare sources for emergency care. We discuss each in turn below.

Prior to the 1980s, lead was used extensively in household paint and plumbing, particularly in the lining and soldering joints of copper pipes to help avoid leaks. Because of health risks, such materials have been banned from new housing. Communities with older housing, such as those in Flint, are particularly vulnerable to lead contamination due to lack of investment in new plumbing.

Chronic exposure to lead has significant health consequences. High levels of lead in the bloodstream are associated with cardiovascular problems, high blood pressure, and developmental impairment affecting sexual maturity and the nervous system (ATSDR, 2007; Zhu et al., 2010). Newer research, however, shows adverse outcomes at low levels of exposure as well (Canfield et al., 2003; Jusko et al., 2008; Lanphear et al., 2005; Menke et al., 2006; Navas-Acien et al., 2007; Tellez-Rojo et al., 2006; Hollingsworth and Rudik, 2019). Reports from Flint suggest that children's blood lead levels increased within a few months following the water change (HannaAttisha et al., 2016; Zahran et al., 2017), while fertility rates dropped substantially (Grossman and Slusky, 2019).

We also contribute to the literature investigating unintended consequences of environmental and informational shocks. While these unintended consequences are generally negative, this is not always the case. Deryugina and Molitor (2019) find that Medicare beneficiaries displaced by Hurricane Katrina who moved to lower mortality areas had lower mortality rates following the disaster. Additionally, this research relates to a strand of literature studying behavioral responses to health information. For example, Oster (2018) finds that 
individuals decrease calorie count of purchased food immediately after receiving a diabetes diagnosis and shift to a healthier diet long term, while Chang (2018) finds that parents are more likely to delay or forego vaccinations for their children following (false) information about autism risk.

In our study, we find that the information shock of the lead advisory induced children to visit a primary care physician. The likelihood of seeking preventive care and access to primary care physicians are correlated positively with household income (Sommers et al., 2017; Pitts et al., 2010) and negatively with ED visits (Cecil et al., 2016). Others have attempted to study the causal effect of primary care on ED visits by incentivizing patients to visit their primary care physician (Bradley et al., 2012, 2018; Bradley and Neumark, 2017) and by temporally increasing Medicaid reimbursements (Polsky et al., 2015; Candon et al., 2018; Decker, 2018; Neprash et al., 2018; Alexander and Schnell, 2019). The effects of these interventions depend on participants' insurance status. Using an RCT design, Bradley et al. (2018) find that those receiving cash incentives are more likely to see a primary care physician and less likely to have a preventable ED visit. However, they find no change in overall costs due to an increase in outpatient visits. We build on this research by investigating an information shock to explore a similar research question in a quasiexperimental setting.

Lastly, this paper studies the effect of creating a linkage to the healthcare system in the form of having a source of usual care. Children who have a usual source of care are more likely to receive preventive care and have higher quality of care, as well as less likely to receive care from the ED (Ettner, 1996; Xu, 2002; Starfield and Shi, 2004; Paustian et al., 2014). This informational shock induces parents to take children for lead tests and provides them with potential alternate places of service to the ED. Previous work has focused on the partial Medicaid expansion to study 
the effects of gaining insurance coverage on low-income individuals' ED and primary care usage (e.g., DeLeire et al., 2013; Sharma et al., 2017; Sommers et al., 2016; Gingold et al., 2017; Jacobs, Kenney, and Selden, 2017; Klein et al., 2017; McConville et al., 2018; Ladhania et al., 2019; Pickens et al., 2019), or how the availability of retail clinics affects both primary care and ED utilization (e.g., Ashwood et al. 2016; Alexander, Currie, and Schnell, 2019). Our paper differs from these studies in multiple ways. First, our population of interest is eligible for Medicaid throughout this time period, so there are no formal coverage expansions. Second, we know of no major changes in clinics' locations or availability in this time period. Third, our affected population experiences an information shock that results in additional primary care usage. We focus our analyses on this variation.

The remainder of the paper proceeds as follows. First, we summarize the events surrounding the Flint water contamination. Next, we discuss the data and methods used to identify changing utilization of medical services. The following section presents results. We then discuss our findings in the context of the Flint contamination and conclude.

\section{Background on the Flint Water Switch}

In spring 2013, as part of an effort to reduce the budget of a city under emergency management, the state-appointed manager of Flint ordered the city to change its water supply to the Flint River by April 25, 2014 (Kennedy, 2016). Previously, the Detroit Water and Sewerage Department (DWSD) provided water to the city sourced from Lake Huron. The switch was intended to be a temporary measure until a proposed pipeline could be completed to supply Flint with water from Lake Huron independently. ${ }^{3}$ The Flint Water Service Center (FWSC), however,

\footnotetext{
${ }^{3}$ The pipeline was expected to take approximately 2 years.
} 
was ill-equipped to supply adequate quality water to the city. It had not supplied the city since 1967 and was not given a sufficient transition period to build up materials, facilities, and expertise to do so (Masten et al., 2016).

The shortcomings of the new facility became apparent soon after the switch. Initially, the water was underchlorinated, resulting in water boil advisories issued in July and August 2014 to counteract E. coli and coliform bacteria detected in the water supply. While chlorine levels were adjusted throughout the summer months to address the bacterial presence, corrosion inhibitor levels were not. In October 2014, the General Motors engine plant in Flint switched to an alternate water source because the water's corrosiveness was adversely affecting its engine parts.

During this time, the water supply was highly corrosive, causing red water and other discoloration throughout the water system, as well as an unusually large number of water main breaks (Masten et al., 2016). The heavily chlorinated water corroded the lining of city and residential pipes, leaching lead from the outdated water pipes into the water supply.

The first high lead measurements in the city were detected in February 2015. City authorities assured residents that these measurements were outliers and that the water was safe to drink. By August 2015, Marc Edwards at Virginia Polytechnic Institute and State University had analyzed 120 samples from Flint homes, finding that $20 \%$ of samples exceeded the EPA action level of $15 \mu \mathrm{g} / \mathrm{L}$. In September 2015, city authorities acknowledged the widespread lead contamination of the water supply and issued a lead advisory. The city switched back to Lake Huron water treated by the DWSD on October $16,2015 .{ }^{4}$

The timeline of the water contamination presents an interesting challenge to our analysis. While the water supply switch occurred in April 2014 and the city first disclosed high lead

\footnotetext{
${ }^{4}$ A more detailed history of Flint and the water contamination timeline are presented in Appendix A.
} 
measurements in February 2015, residents did not have confirmation of the contamination until September 2015. Although other studies measure the effect of exposure to lead contamination, we focus on the behavioral response to knowledge of the contamination. Thus, our analysis focuses on medical utilization after the city's lead advisory in September 2015, which represents our "treatment" period.

\section{Data}

Through an agreement with the Michigan Department of Health and Human Services (MDHHS), we link vital records for all children born in Michigan in 2013-2015 with their Medicaid claims files for any enrollees in the sample. ${ }^{5}$ This unique dataset has several advantages. First, the dataset includes geocoded maternal residential address at the time of birth. Second, it contains birth certificate information on parental demographic characteristics (e.g., race, age, and educational attainment). Third, the Medicaid data is at the claim level, with detailed information regarding all diagnoses recorded and procedures performed at every visit, as well as provider information. The data also includes monthly eligibility information, which allows us to create a longitudinal panel for each enrollee-even those who abstain from medical use. Fourth, the Medicaid data includes information about payment made for all fee-for-service claims, allowing us to extrapolate payments to the managed-care claims for complete cost information. ${ }^{6}$ Fifth, the linkage of birth records to claims allows us to track children who were born in Flint, irrespective of where they received their care in the years that followed, thus avoiding selection due to

\footnotetext{
${ }^{5}$ The sample includes both fee-for-service and managed care enrollees, as well as those who do not indicate type of plan.

${ }^{6}$ We apply cost information for managed care claims by matching procedure codes with payment made for fee-forservice procedures. Therefore, our cost estimates represent the upper range of costs to Medicaid, though they are closer in line with costs for those who are privately insured.
} 
migration out of the city. These data include Medicaid claims for the years 2013-2016. ${ }^{7}$

We classify all claims for care provided in the emergency department (ED) using the New York University Emergency Department (NYU ED) visit severity algorithm. ${ }^{8}$ To develop the algorithm, emergency physicians reviewed ED records from the 1990s and categorized diagnosis codes (that did not include any alcohol, drug, injury, or mental health elements) into the following categories (Billings, Parikh, and Mijanovich, 2000; validated by Ballard et al., 2010):

- Emergent, ED care needed and non-preventable (e.g., appendicitis)

- Emergent, ED care needed, but would have been preventable given adequate previous non-emergency care (e.g., diabetes, asthma)

- Emergent, care needed within 12 hours, but primary care would suffice (e.g., heartburn, eye pain)

- Non-emergent, care within 12 hours unnecessary (e.g., rubella, sunburn, jaw pain)

These categories are not mutually exclusive, however. Depending on the complexity of the presenting patient most diagnoses should include a mix of these categories. For example, based on other details on the discharge record, out of 100 cases of:

- Croup: $57 \%$ are emergent and non-preventable, $19 \%$ are primary care treatable, and $24 \%$ are non-emergent.

- Cough: $12 \%$ are emergent and non-preventable, $24 \%$ are primary care treatable, and $65 \%$ are non-emergent

- Acute tonsillitis: $6 \%$ are emergent but preventable, $28 \%$ are primary care treatable, and $66 \%$ are non-emergent.

Finally, some diagnoses could not be assigned to a category and so are listed as "unclassified". 9

\footnotetext{
${ }^{7}$ We have received approval to supplement our analysis with Medicaid claims data covering 2017 and 2018 once the data become available.

${ }^{8}$ https://wagner.nyu.edu/faculty/billings/nyued-background

${ }^{9}$ In Appendix G, we present results incorporating a "patch" that captures and classifies a share of uncategorized diagnosis codes (Johnston et al., 2017).
} 


\section{Methodology}

This research allows us to track the use of medical services by children born in Flint between 2013 and 2015, ${ }^{10}$ and compare them to similarly aged children born elsewhere in Michigan. Because we classify children based on the city in which they were born, our estimates are an intent to treat. A priori, we expect to identify higher incidence of adverse health outcomes, increased use of primary care, and increased costs for patients and insurers because of care received following the informational shock described above. ${ }^{11}$

Since the data are observational, we adjust for differences between Flint residents and those in the rest of the state. We follow the estimation method used by Grossman and Slusky (2019), which compares Flint to a subset of other large cities in Michigan. We focus exclusively on Michigan because we have complete Medicaid data for this state. Because we are interested in the behavioral response to information shocks as well as changes in water quality, we focus on September 2015, when Flint first released a public lead advisory. ${ }^{12,13}$

We employ the difference-in-differences empirical strategy presented below:

$$
\text { Outcome }_{i c t}=a+\beta_{1} \text { Flint } * \text { After }_{c t}+\beta_{2} X_{i c t}+\alpha_{c}+\delta_{t}+\varepsilon_{i c t}
$$

in which Outcome is the medical service or procedure for individual $i$ in city $c$ at time $t$ aggregated over the calendar month. Flint*After is a binary variable equal to 1 for claims after September

\footnotetext{
${ }^{10}$ Given the result of Grossman and Slusky (2019) that the Flint water switch affected fertility rates, one might be concerned about compositional changes driving our results. In Appendix D, we limit our analysis to the sample of children born before April 2014 (and so unaffected by the fertility effects of the water switch) and find comparable results.

11 i.e. Flint announcing a potential increase in lead in their water source.

${ }^{12}$ Mona Hanna-Attisha, a Flint pediatrician, held a press conference to announce her findings of a substantial increase in children with high blood lead levels in September 2015; Marc Edwards of Virginia Tech released his team's findings of high blood lead levels in Flint households in August 2015. Flint switched off Flint River water on October 16, 2015.

${ }^{13}$ In Appendix C, we show that the results are robust to starting the treatment period in January 2016, when the Governor of Michigan apologized for the crisis.
} 
2015 to children born in Flint and 0 otherwise. We include a binary variable for the city in which an individual lived at time of birth, $\alpha_{c}$, which controls for time-invariant characteristics of a city, and year and month of service as well as year and month of birth fixed effects, $\delta_{t}$, which control for general trends and seasonality in receipt of medical services. These fixed effects subsume the main effects for Flint and After. $X_{i c t}$ are individual-level characteristics. A potential confounder in our study is that the state of Michigan expanded Medicaid coverage through the ACA in 2014. To the extent that this expansion affected all parts of Michigan equally, time fixed effects will account for overall trends in Michigan. ${ }^{14}$ We investigate the percentage of the sample reporting: any lead test, any office visit, any vaccine, any ED visit, any claim, and any payment. We also investigate the total number of lead tests, office visits, vaccines, ED visits, and claims, as well as the total payments made. Standard errors are clustered at the city level to allow for serial correlation (Abadie et al., 2017). Additionally, we use wild bootstrap methods to adjust our inference because we only have one treated area (Cameron, Gelbach, Miller, 2008). ${ }^{15}$

We use a modified version of the above equation to investigate the impact of the water switch on different types of ED visits, as defined by the NYU algorithm. For each category, we construct a per capita outcome variable at the individual-month level by summing the fractional shares of each claim in that category. For example, if an individual had two discharges in a given month, one that was $20 \%$ preventable with primary care and another that was $70 \%$ preventable with primary care, we assign a value of 0.9 , representing $90 \%$ of a primary-care-preventable visit. Anyone without an ED claim in that category (or with no ED claims at all) receives a value of 0.

\footnotetext{
${ }^{14}$ This issue is further mitigated in that the ACA expansion affected adults and did not change federal poverty-level coverage thresholds for those in our age cohort.

${ }^{15}$ As an additional robustness check, we perform randomized inference permutation tests (see e.g. Fisher, 1935; Cunningham and Shah, 2018)
} 
While coding those with no claims as having zero visits in a linear specification may bias the results (as some of the individuals would ideally have a negative number of emergency room visits), this bias would be toward zero, and so we consider our set up to be a lower bound on the true effect. We establish our intuition for this setup with three thought experiments. First, imagine that all ED visits are $100 \%$ preventable with primary care. Then, to estimate the reduction in per capita ED visit results from a shock to primary care, one would assign 0 to those without an ED visit, and the number of visits to anyone with an ED visit.

For the second thought experiment, imagine that some ED visits are 100\% nonpreventable. The primary care shock should not affect these visits, and so individuals with only these visits should still be assigned a value of 0 for the outcome variable.

Finally, consider our actual situation, in which certain diagnoses are sometimes preventable and sometimes not. We only care about the preventable parts for our primary estimate, and so in aggregate we can add up the preventable shares of each one to get the outcome variable.

A final note is that the NYU ED algorithm is designed for the entire population, not specifically for children. This is a known limitation of the algorithm, recognized by its developers (Billings, Parikh, and Mijanovich, 2000). However, lacking a child-specific algorithm, we consider this a valid starting point for our analysis.

We estimate the elasticity of substitution by comparing magnitudes of the effect of the Flint water contamination shock on ED visits and primary care visits relative to their respective means. ${ }^{16}$

A potential challenge to our identification is that the estimated differences could be attributed to the emergency management in Flint that began in December 2011, rather than the

\footnotetext{
${ }^{16}$ Appendix J describes in detail the standard procedures for lead tests. While there is a plausible concern that parents might bring children to the ED for lead tests, our review of provider surveys reported in the literature suggests that this is rare and that most physicians in these situations refer children to primary care.
} 
water contamination. To rule out a trend in outcomes of interest prior to September 2015, as well

as to explore its dynamics month to month, we estimate an extended form of specification (1)

where the time period is disaggregated into monthly indicators:

$$
\text { Outcome }_{i c t}=a+\sum_{j} \beta_{1 j} \text { Flint } * \text { Mont }_{c j}+\beta_{2} X_{i c t}+\alpha_{\mathrm{c}}+\delta_{\mathrm{t}}+\varepsilon_{i c t}
$$

where Flint $*$ Mont $h_{c j}$ is a monthly indicator for an individual residing in Flint and $\beta_{1 j}$ estimates

the difference in claims in month $j$ between children born in Flint and control cities with respect

to September $2015 .^{17}$

\section{Results}

Before proceeding with the analysis, we use an event study specification to justify selection of September 2015 as the beginning of the treatment period. Figure 1 shows results for our event study specification, showing differences in monthly lead tests for children born in Flint compared to those in control cities. ${ }^{18,19}$ Each point shows the difference in number of lead tests for children born in Flint compared to control cities with respect to September $2015 .^{20}$ The whiskers on each estimate provide the $95 \%$ confidence interval. The graph shows a clear rise in lead tests after

\footnotetext{
${ }^{17} \mathrm{We}$ perform similar analyses at the quarterly level as well. These results are presented in Table 4 and Figure 2.

${ }^{18}$ To ease potential concerns of increased volatility in lead test results before May 2014, Appendix F shows consistent results starting with the pre-period in May 2014.

${ }^{19}$ The primary control cities are the other most populous cities in Michigan (Ann Arbor, Dearborn, Detroit, Farmington Hills, Grand Rapids, Kalamazoo, Lansing, Livonia, Rochester Hills, Southfield, Sterling Heights, Troy, Warren, Westland, and Wyoming). Appendix K shows comparable results using alternative smaller control cities with histories of high lead levels in their drinking water (Detroit, Grand Rapids, Kalamazoo, Lansing, Wyoming, Battle Creek, Port Huron, Hamtramck, and Saginaw; see Urban, 2018).

${ }^{20}$ The American Academy of Pediatrics (AAP) recommends that children be tested for lead levels at ages 1 and 2; it also suggests lead screening for older children who have not been tested. During the period covered by this study, the AAP changed its recommendation to venous blood draws for testing, noting that finger-prick sample testing yielded a high rate of false positives. The AAP lists Lead Screening in Children using CPT Code 83655, which we use in our analysis. The code does not allow for differentiation between finger-prick or venous blood tests. Because venous tests are more difficult to administer, this may introduce more heterogeneity among children who receive the test in Flint compared to other cities after the contamination became known. Though we would like to account for different methods of testing, we are not able to do so.
} 
September 2015, with a sharp peak in January and February 2016. The graph also shows no significant trend prior to September 2015, suggesting that despite ongoing speculation, the announcement of elevated residential tests by city authorities marked the beginning of Flint residents changing their behavior with respect to health care receipt for their children.

Table 1 shows summary statistics and unadjusted difference-in-differences estimates. In Panel A, we see minimal changes in the demographic characteristics in our sample population. Following the information shock, receipt of any lead test nearly doubles in Flint compared to a small increase in comparison areas. The unadjusted difference-in-differences results show a 1.6 percentage point increase in lead tests among children in Flint compared to others, but much more modest changes in other types of health care, except ED visits, which we discuss in greater detail below. We also see a small increase in payments in Flint compared to other cities. It is important to note that the after period (9/2015-2016) is much shorter than the lookback period (2013-9/2015). In Panel B, we find no change in unavoidable ED visits, but decreases in all three of the avoidable or non-emergent categories.

\section{Main Results}

Table 2 shows our primary difference-in-differences results. Using September 2015 as the treatment date (when the independent evidence of increases in lead exposure became public), the likelihood of receiving any lead test increased by 1.7 percentage points (pp), a 49 percent increase. We estimate a small, statistically insignificant decrease in the share of individuals having any office visits. Interestingly, given our results below, we see a slight, marginally significant decrease in the share of children with an ED visit. This is possibly because ED visit is a heterogeneous measure including unclassified visits, which could be dampening the power of our analysis. Any 
claims and any payments increase by 1.8 and $1.7 \mathrm{pp}$, respectively. These represent a 4 percent increase in both categories.

In panel B we examine the total number rather than an indicator for any receipt. The results are unsurprisingly quite similar for lead claims, as individuals likely only receive at most one lead test per month. However, vaccinations demonstrate a potential positive spillover effect of receiving primary care for other services, with vaccinations increasing 13 per 1000 person-months (16\%) in Flint compared to other areas following the information shock (Carpenter and Lawler, 2019). Finally, claims increase by 7.3 per 1000 person-months (2\%), while overall payments increase $\$ 12$ (3\%), which is only marginally statistically significant. This suggests that even if lead tests and their related office visits are substituting for ED visits, they may be doing so at such a low rate that overall healthcare spending increases.

Table 3 contains results using the per capita measures of ED visits calculated using the method described above. We find no change in the number of non-preventable ED visits. For each of the other three types, our estimates indicate a decrease of between 1 and 2 visits per thousand enrollees per month. While our estimate for visits that were treatable in primary care is statistically insignificant overall, we show later that this hides important increases in office visits immediately following the information shock (Table 4). We create two composite metrics: (1) PC sensitive, a combination of primary care treatable and non-emergent; and (2) Avoidable, a combination of primary care preventable, primary care treatable, and non-emergent. All show strongly statistically significant decreases in ED visits per capita. The information shock in Flint is associated with nearly 5 fewer avoidable ED visits per enrollee-month, a decrease of 8.2 percent.

We perform quarterly analyses on office visits, avoidable ED visits, and payments in Table 4 and Figure 2. The motivation for this analysis is that in Figure 1 we find a very large increase in 
lead tests only at specific times, most notably September 2015 and January 2016. To test our hypothesis that this increase in lead tests should also increase office visits, we separate our results by post-information shock quarter. Our results suggest that immediately following the information shock, office visits increase by $0.9 \mathrm{pp}(4 \%)$, while they increase by $2.7 \mathrm{pp}(11 \%)$ in the first quarter of 2016. Office visits decrease in the last two quarters of treatment in Flint compared to control areas. Avoidable ED visits initially remain constant, but then decrease substantially and with statistical significance for the rest of the treatment period. This suggests an initial increase in office visits having a prolonged effect on ED visits. One way to explain these results is that this initial increase in office visits created a link between the patient (and his or her parents) and the healthcare system. ${ }^{21}$ We explore this idea in more detail in the mechanism section.

To further explore whether these substitutions are driven by lead-sensitive conditions or reflect a more general shift in utilization, we repeated the analysis, restricting the sample to the most common Clinical Classification Software $(\mathrm{CCS})^{22}$ categories in the ED prior to September 2015. CCS categories were developed by the Healthcare Cost and Utilization Project of the Agency for Healthcare Research and Quality to classify ICD-9 diagnoses and procedures into clinically meaningful categories.

For this analysis, we identified the 10 most commonly occurring CCS categories in the ED that correspond to claims predating September 2015 with diagnoses classed by the NYU algorithm as avoidable. ${ }^{23}$ These CCS categories encompass over $86 \%$ of all avoidable claims in the ED and

\footnotetext{
${ }^{21}$ For example, care for a child who was previously brought in to the ED for asthma flare-ups has shifted to a physician's office. An in-office inhaler prescription not only prevents future flare-ups that would necessitate ER visits, but also reduces future office visits, as the condition is appropriately maintained.

${ }^{22}$ https://www.hcup-us.ahrq.gov/toolssoftware/ccs/ccs.jsp

${ }^{23}$ For this classification, we limited claims to those with any avoidable component in diagnoses, then identified the 10 most common CCS categories within that subsample of claims. We chose to focus on CCS categories because classifying diagnoses is too specific and not sufficiently informative. This also allows us to impute avoidability of
} 
are listed in Table 5. Next we aggregated claims to the person-month-CCS category, so that for each individual in our data, we have monthly use indicators, now split by CCS category. We excluded all individuals with no claims in the CCS category for that month. As with the personmonth analysis, we sum the NYU Algorithm indicators for preventable and non-preventable ED care. We re-estimate our specification for two venues of care: office visits (all diagnoses in each CCS category) and ED (only avoidable shares as defined above).

We present results from this analysis in two formats. Figure 3 shows coefficient estimates by CCS category for any office visits (Panel A), avoidable ED visits (Panel B), and a scatterplot by category (Panel C). Table 6 then tests the hypothesis that in each CCS category the increase in office visits is accompanied by a decrease in avoidable ED visits. Looking at Figure 3, we see that in 6 of 9 CCS categories, office visits (Panel A) increase, with 5 of those 6 increases being statistically significant. Preventable ED visits (Panel B), on the other hand, decline in 6 of 9 categories. Comparing specific CCS categories, we particularly notice a sharp increase in office visits for skin and subcutaneous tissue infections, and a decrease in associated preventable ED visits. Abdominal pain is another category with a sharp increase in office visits and a decrease in preventable ED visits, as is gastritis and duodenitis. Comparing the office visit and avoidable ED visits by condition (Panel C), we see a clear negative, linear relationship between the two results, with a greater increase in the share of children having any office visits causing a greater reduction in avoidable ED visits per capita. ${ }^{24}$

In Table 6 we present the results of a chi square test that compares the estimated change in office visits to that of preventable ED visits, $\left(\mathrm{H}_{0}: \beta_{\text {OfficeVisits }}=-\beta_{\text {AvoidableEDVisits }}\right)$, by CCS

CCS category based on these most common diagnoses, but by including all diagnoses in a given CCS category we avoid defining this category too narrowly.

${ }^{24}$ Appendix E shows a similar relationship between total office visits and avoidable ED visits. 
category. The chi square test fails to reject the null in any category, suggesting that, indeed, the increase in office visits is statistically indistinguishable from the decrease in preventable ED visits. Mechanisms

To test the role of lead testing in the potential mechanisms for changing medical utilization, we use individuals' episodes of care to explore choices in primary and ED care following the administration of a lead test. Our main results suggest that the contamination increased awareness of primary care through increased interaction with a physician or clinic. To examine this further, our analysis focuses on treatments received in the three months following a lead test to identify changing trends in utilization in Flint after September 2015.

The results of medical utilization in the post-lead test period are reported in Table 7. Here, the sample is limited to visits in the 3-month period following a lead test (columns (1)-(4)). We find statistically significant increases in the likelihood of indicators of established care: $3.7 \mathrm{pp}$ increase in immunization, 2.9pp increase in well-visits, $8 \mathrm{pp}$ increase in seeing the same provider, 14.8pp increase in using the same clinic. These results strongly suggest that following the information shock, Flint residents who received a lead test were more likely to continue to receive regular care from the same clinic. It follows from this result that should a child become ill after having received a lead test, a parent would likely take the child back to the clinic at which he or she received this test to see the same physician. Parents who had not taken their child to receive a lead test would be more likely to take their sick child to the ED.

Pre-Trend Analysis

To test the validity of our specification, as well as to discern monthly trends of our analysis, we estimate the event study proposed in equation (2). The estimates of $\beta_{1 j}$ are presented graphically in Figure 4; each point represents the difference in outcome between Flint and control 
cities relative to September 2015. Panel (A) shows results for number of claims, Panel (B) represents any office visits, and Panel (C) reflects preventable ED visits. All three panels show that, despite seasonal variation, there is no discernable trend in these outcomes prior to September 2015, validating our use of the difference-in-differences estimation method. Furthermore, we note a sustained increase in claims and office visits in the treatment period.

\section{(Slightly) Longer Term Effects}

Though quarterly analysis in Figure 2 shows declining office and avoidable ED visits in the latter half of 2016 following the increase in office visits immediately after the information shock, it is untested whether the prevention effect of office visits lasts beyond this initial period. To explore the medium-term changes of the initial rise in office visits we extend the analysis to 2017 in Figure $5 .{ }^{25}$ We find that the decline in office and avoidable ED visits persists through 2017, suggesting that the benefits of increased office care are longer lasting. Consistent with the shorter-term results, however, the decline in avoidable ED visits is larger than the decline in office visits.

\section{Robustness Checks}

We include several robustness checks in the appendices. This includes stratifying our sample to children born to black mothers (Table B1), children in fee-for-service Medicaid (Table B2), and children in managed care plans (Table B3). ${ }^{26}$ Our estimates follow a similar pattern; we continue to see a sizable decrease in avoidable ED visits in each of these samples. We also start treatment in January 2016 instead of September 2015 (Table C1) and limit the sample to the cohort

\footnotetext{
${ }^{25}$ Appendix N contains the table form of Figure 5.

26 The lack of a populated fee-for-service / managed care indicator for half of the claims substantially reduces our sample size and therefore statistics precision in these tables.
} 
of children born before April 2014 to avoid potential bias from endogenous fertility (Grossman and Slusky, 2019) and/or worse health at birth following the water change (Abouk and Adams, 2018; Wang et al., 2019) (Table D1). Results are robust to these alternate sample definitions. We also start the pre-period in May 2014 (Table F1) and use the "patched" NYU Algorithm (Table G1), per Johnston et al. (2017). Additionally, to test the sensitivity of our findings to the treatment period, we estimated a flexible form specification, with two treatment periods - January to August 2015 and September 2015 to December 2016 - and get qualitatively and quantitatively similar results, which we report in Appendix $\mathrm{H}$.

To address concerns that the substantial increase in lead tests from our main results is driven by a non-representative sample of the broader population, we investigate whether those receiving lead tests after the information shock differ from those receiving tests prior to it. Table I1 presents results for demographic characteristics including sex, race, and maternal age using a difference-in-differences framework; it shows no change in characteristics of those seeking lead tests after the information shock.

One might also be concerned that choosing comparison cities by population may result in non-comparable groups with regards to lead levels. Appendix K repeats our main analysis using an alternate control group of cities (including smaller ones) with histories of high lead levels (Urban, 2018) and finds comparable results. ${ }^{27}$

To explore when office visits matter, we separately estimate our results by weekday (Table L1) and weekend (Table L2). Individuals are less likely to get an office visit on a weekend, so we expect to see our main results driven by changes on the weekday. Overall, we find evidence of

\footnotetext{
${ }^{27}$ We additionally perform an analysis adding Pontiac and Muskegon to our main analysis, as these cities may be more comparable to Flint, with consistent results.
} 
this: rates of lead tests, office visits, and avoidable ED visits are higher on weekdays, as expected. Additionally, the lead test effects on weekdays are nearly identical to our main results, while the effect on weekends is close to zero (and this difference is statistically significant at the $0.1 \%$ level). While we find some statistically significant results for weekends, these are rare outcomes, thus very small changes may drive these effects. For avoidable ED visits, the decrease following the information shock coefficient for Flint on weekdays is approximately twice as large as on weekends. However, the percentage change in these variables is not as stark ( $8 \%$ on weekdays compared to $6 \%$ on weekends).

Finally, we perform randomization inference permutation tests for our main results: any lead test, avoidable visit, and non-preventable visit (following Fisher, 1935; Cunningham and Shah, 2018; and Grossman and Slusky, 2019). These tests compare the coefficient in our main analyses to a distribution of coefficients when we systematically assign treatment to each individual control city. Comparing our actual result for Flint to this distribution of treatment effects allows us to assign statistical significance if our Flint effect is an outlier. For any lead test, the Flint coefficient is the most extreme by far, suggesting statistical significance. For avoidable visits, the Flint coefficient is also the largest negative number, although there are positive coefficients of greater magnitude. We are less concerned with these positive effects, as our hypothesis is one sided (i.e., that avoidable visits will decrease). For non-preventable ED visits, the coefficient for Flint is closer to zero than any of the results for other cities, suggesting no effect.

\section{Discussion}

The results in Figure 2 show that definitive public information about Flint's water supply led to a 4 percent increase in office visits in quarter 4 of 2015, the first treatment quarter. Office 
visits increased by 11 percent in the first quarter of 2016. From Table 3, column (6), we find a decrease of 4.9 visits per thousand person-months, which on a mean of 59 per thousand represents an $8 \%$ decrease. Dividing the percent change in avoidable ED visits by the percent change in office visits provides us with an estimate of elasticity of substitution between primary and ED care of between -0.5 and -2.2 .

Figure 3 then breaks this result down by common diagnosis classifications that are often avoidable. In addition to our results not being driven by one or two conditions, we generally see a negative relationship between the magnitude of the effect on office visits for a particular condition and the magnitude of the effect on avoidable ED visits for that same condition. For upper respiratory infections; skin and subcutaneous tissue infections; abdominal pain, gastritis, and duodenitis, we find precisely estimated and opposite effects. A chi-squared test of parity between the magnitudes of the estimated coefficients $\left(\mathrm{H}_{0}: \beta_{\text {OfficeVisits }}=-\beta_{\text {AvoidableEDVisits }}\right)$ yields statistically insignificant results, suggesting we cannot reject the null that these estimates are of equal magnitude and oppositely signed. We are hesitant in interpreting this test, as it may lack the specificity to reject our null hypothesis. However, this lends credence to our postulation that increased office visits prevent avoidable ED visits.

Despite this substitution from potentially avoidable ED visits to office visits, we also find a statistically significant increase in total Medicaid spending. We attribute this to the relative frequency of each type of visit; given the vast difference in the share of enrollees with any ED visit (0.091) in a given month vs. any office visit $(0.265)$, the absolute increase in office visits and associated testing costs more than the savings from prevented ED visits. These results are consistent with literature that shows that increasing use of preventive care is not associated with savings in overall cost of care (Danagoulian, 2018; Jones, Molitor, and Reif, 2019). Though we do 
not observe reduced costs, we know that establishing usual source of care is welfare improving, particularly for children (Ettner, 1996; Xu, 2002; Starfield and Shi, 2004; Paustian et al., 2014). Nevertheless, it is worth estimating the aggregate impact of healthcare costs following the water switch and comparing it to the proposed savings from the water switch. 1.61 million enrollee months for the entire 2013-2016 data correspond to 62,258 enrollees. Of those, approximately 3800 enrollees resided in Flint in the treatment period. Taking the $\$ 12 /$ month coefficient from Table 2 and multiplying it by 3800 and by 12 months provides an estimate of approximately $\$ 550,000$ additional Medicaid spending per year.

Flint city officials estimated that the water switch could save the city $\$ 2.5$ million a year. ${ }^{28}$ This means that Michigan Medicaid alone spent more than $20 \%$ of the projected savings on Flint enrollees between the ages of 0 and $3 .^{29}$ This does not include the future costs of any resulting health conditions, the current health costs of individuals above the age of 3 , or productivity losses of the Flint labor force. ${ }^{30}$

\section{Conclusion}

As the intensity of exposure to environmental pollutants decreases with improved regulation and control, health outcomes will improve and subsequent treatments associated with exposure will decrease. This, however, does not negate the burden imposed by such

\footnotetext{
${ }^{28} \mathrm{https}: / / \mathrm{www} . \mathrm{mlive.com} /$ news/flint/index.ssf/2015/01/flints_dilemma_how_much_to_spe.html

${ }^{29}$ According to the Kaiser Family Foundation, the federal government would cover approximately $71 \%$ of these costs. https://www.kff.org/medicaid/state-indicator/federalstate-share-ofspending/?currentTimeframe $=0 \&$ sortModel $=\% 7 \mathrm{~B} \% 22$ colId $\% 22: \% 22$ Location $\% 22, \% 22$ sort $\% 22: \% 22$ asc $\% 22 \% 7 \mathrm{D}$

${ }^{30}$ Future analysis will include testing the impact of the information shock on the flow of eligible Medicaid patients enrolling in Medicaid. We will also incorporate CMS provider data to enable study of heterogeneity on the physician side.
} 
contaminations on communities, as the anxiety and uncertainty associated with such exposure increase, among other things, utilization of all medical services. This paper identifies the opportunities inherent when such environmental disasters expand awareness of health and health care.

Our findings show that residents of affected communities often turn to health care providers for guidance on appropriate response. Because the population studied here is low-income Medicaid-covered young children, our findings directly benefit communities and policymakers attempting to determine what to emphasize (e.g., education, screening, remediation) to counteract potential negative health effects of environmental pollutant exposure in early childhood.

Furthermore, the Flint water switch led to increases in lead tests and associated office visits and gives us a unique opportunity to study the substitution between office visits and potentially avoidable ED visits. While we find suggestive evidence of substitution, we do not find overall healthcare cost savings. Our results emphasize that moving care from the ED into the primary care setting should not be pursued for its cost savings but, rather, for improved quality of care. These results are specific to a cohort aged 0 to 3 years old and may not be generalizable to the general public.

This work documents the important role information can play in improving health care receipt for disadvantaged populations. Lead tests prompted parents to seek care for their children at the same clinics from which they received lead tests, reducing their likelihood of going to the ED for avoidable conditions. This may have important ramifications for any situation in which individuals are induced to seek care more often in primary care settings. 


\section{References}

Abadie, A., S. Athey, G. Imbens, and J. Wooldridge. 2017. When Should You Adjust Standard Errors for Clustering? NBER Working Paper No. 24003.

Abouk, R., and S. Adams. 2018. Birth Outcomes in Flint in the Early Stages of the Water Crisis. Journal of Public Health Policy 39: 68-85.

Alexander, D., and M. Schnell. 2019. The Impacts of Physician Payments on Patient Access, Use, and Health. NBER Working Paper No. 26095.

Alexander, D., J. Currie, and M. Schnell. 2019. Check Up Before You Check Out: Retail Clinics and Emergency Room Use. Forthcoming, Journal of Public Economics.

Antwi, Y.A., Moriya, A.S. and K.I. Simon. 2015. Access to health insurance and the use of inpatient medical care: Evidence from the Affordable Care Act young adult mandate. Journal of Health Economics, 39, pp.171-187.

Ashwood, J. S., M. Gaynor, C. M. Setodji, R. O. Reid, E. Weber, and A. Mehrotra. 2016. Retail Clinic Visits for Low-Acuity Conditions Increase Utilization and Spending. Health Affairs 35(3): 449-55.

ATSDR (Agency for Toxic Substances and Disease Registry). 2007. Toxicological Profile for Lead. Case No. 7439-92-1. Atlanta, Georgia: ATSDR. Available at: http://www.atsdr.cdc.gov/toxprofiles/tp13.pdf.

Ballard, D. W., et al. 2010. Validation of an Algorithm for Categorizing the Severity of Hospital Emergency Department Visits. Med Care 48(1): 58-63.

Billings, J., N. Parikh, and T. Mijanovish. 2000. Emergency Room Use: The New York Story. The Commonwealth Fund Issue Brief: 1-11.

Bradley, C. J., and D. Neumark. 2017. Small Cash Incentives Can Encourage Primary Care Visits By Low-Income People With New Health Care Coverage. Health Affairs 36(8): $1376-1384$.

Bradley, C. J., S. O. Gandhi, D. Neumark, S. Garland, and S. M. Retchin. 2012. Lessons for Coverage Expansion: A Virginia Primary Care Program for the Uninsured Reduced Utilization and Cut Costs. Health Affairs 31(2): 350-9.

Bradley, C.J., Neumark, D. and L. S. Walker. 2018. The effect of primary care visits on other health care utilization: A randomized controlled trial of cash incentives offered to low income, uninsured adults in Virginia. Journal of Health Economics, 62, pp.121-133.

Cameron, A. C., J. B. Gelbach, and D. L. Miller. 2008. Bootstrap-Based Improvements for Inference with Clustered Errors. Review of Economics and Statistics 90(3): 414-427. 
Candon, M., S. Zuckerman, D. Wissoker, B. Saloner, G. M. Kenney, K. Rhodes, and D. Polsky. 2018. Declining Medicaid Fees and Primary Care Appointment Availability for New Medicaid Patients. JAMA Intern Medicine 178(1): 145-146.

Canfield, R.L., Henderson Jr, C.R., Cory-Slechta, D.A., Cox, C., Jusko, T.A. and B. P. Lanphear. 2003. Intellectual impairment in children with blood lead concentrations below $10 \mu \mathrm{g}$ per deciliter. $N$ Engl J Med, 348(16), pp.1517-1526.

Carpenter, C. S., and E. Lawler. 2019. Direct and Spillover Effects of Middle School Vaccination Requirements. American Economic Journal: Economic Policy 11(1): 95125.

Cecil, E., A. Bottle, T.E. Cowling, A. Majeed, I. Wolfe, and S. Saxena. 2016. Primary Care Access, Emergency Department Visits, and Unplanned Short Hospitalizations in the UK. Pediatrics, 137(2): e20151492.

Chang, L.V. 2018. Information, Education, and Health Behaviors: Evidence from the MMR Vaccine Autism Controversy. Health Economics 27(7): 1043-1062.

Cunningham, S., and M. Shah. 2018. Decriminalizing Indoor Prostitution: Implications for Sexual Violence and Public Health. Review of Economic Studies 85, 1683-1715.

Danagoulian, S. 2018. Policy of Prevention: Medical Utilization Under a Wellness Plan. Health Economics 27: 1843-1858. https://doi-org.proxy.lib.wayne.edu/10.1002/hec.3806.

Decker, S. 2018. No Association Found Between the Medicaid Primary Care Fee Bump and Physician Reported Participation in Medicaid. Health Affairs 37(7): 1092-1098.

DeLeire, T., L. Dague, L. Leininger, K. Voskuil, and D. Friedsam. 2013. Wisconsin Experience Indicates That Expanding Public Insurance to Low-Income Childless Adults Has Health Care Impacts. Health Affairs 32(6): 1037-1045.

Deryugina, T. and D. Molitor. 2018. Does when you die depend on where you live? Evidence from Hurricane Katrina. National Bureau of Economic Research Working Paper No. w24822.

Ettner, S. L. 1996. The Timing of Preventive Services for Women and Children: The Effect of Having a Usual Source of Care. American Journal of Public Health 86(12): 1748-54.

Finkelstein, A.N., Taubman, S.L., Allen, H.L., Wright, B.J. and K. Baicker. 2016. Effect of Medicaid coverage on ED use-further evidence from Oregon's experiment. $N$ Engl $J$ Med; 375:1505-1507.

Fisher, R. A. 1935. The Design of Experiments. Edinburgh, Scotland: Oliver and Boyd.

Gingold, D. B., R. Pierre-Mathieu, B. Cole, A. Miller, and J. Khaldun. 2017. Impact of the Affordable Care Act Medicaid Expansion on Emergency Department High Utilizers with 
Ambulatory Care Sensitive Conditions: A Cross-Sectional Study. American Journal of Emergency Medicine 35(5): 737-742.

Grossman, D., and D. Slusky. 2019. Lead in the Water and Birth Outcomes: The Case of Flint. Forthcoming, Demography.

Grumbach, K., D. Keane, and A. Bindman. 1993. Primary Care and Public Emergency Department Overcrowding. American Journal of Public Health 83(3): 372-378.

Hanna-Attisha M., J. LaChance, R. C. Sadler, and A. Champney Schnepp. 2016. Elevated Blood Lead Levels in Children Associated with the Flint Drinking Water Crisis: A Spatial Analysis of Risk and Public Health Response. American Journal of Public Health 106: 283-290.

Hollingsworth, A., and I. Rudik. 2019. The Social Cost of Leaded Gasoline: Evidence from Regulatory Exemptions. SocArXiv, 23 Sept. Web: https://osf.io/preprints/socarxiv/rdy6g/

Jacobs, P. D., G. Kenney, and T. Selden. 2017. Newly Eligible Enrollees In Medicaid Spend Less And Use Less Care Than Those Previously Eligible. Health Affairs 36(9): 16371642.

Johnston, K. J., L. Allen, T. A. Melanson, and S. R. Pitts. 2017. A "Patch" to the NYU Emergency Department Visit Algorithm. Health Services Research 52(4): 1264-1276.

Jones, D., D. Molitor, and J. Reif. 2019. What do Workplace Wellness Programs do? Evidence from the Illinois Workplace Wellness Study. Quarterly Journal of Economics 134.4: 1747-91. ProQuest. Web. 16 Feb. 2020.

Jusko, T.A., Henderson Jr, C.R., Lanphear, B.P., Cory-Slechta, D.A., Parsons, P.J. and R. L. Canfield. 2008. Blood lead concentrations $<10 \mu \mathrm{g} / \mathrm{dL}$ and child intelligence at 6 years of age. Environmental Health Perspectives, 116(2), pp.243-248.

Klein, E., et al. 2017. The Effect of Medicaid Expansion on Utilization in Maryland Emergency Departments. Annals of Emergency Medicine 70(5): 607-614.

Ladhania, R., A. Haviland, A. Venkat, R. Telang, and J. Pines. 2019. The Effect of Medicaid Expansion on the Nature of New Enrollees' Emergency Department Use. Forthcoming, Medical Care Research and Review.

Lanphear, B.P., 2005. Origins and evolution of children's environmental health. Environmental Health Perspectives, 113(8-1), p.24.

Masten, S. J., S. H. Davies, and S. P. Mcelmurry. 2016. Flint Water Crisis: What Happened and Why? Journal of the American Water Works Association 108(12): 22-34.

McConville, S., M. Raven, S. Sabbagh, and R. Hsia. 2018. Frequent Emergency Department Users: A Statewide Comparison Before and After Affordable Care Act Implementation. Health Affairs 37(6): 881-889. 
Menke, A., Muntner, P., Batuman, V., Silbergeld, E.K. and E. Guallar. 2006. Blood lead below $0.48 \mathrm{mmol} / \mathrm{L}(10 \mathrm{mg} / \mathrm{dL})$ and mortality among US adults. Circulation, 114(13), pp.13881394.

Navas-Acien, A., Guallar, E., Silbergeld, E.K. and S.J. Rothenberg. 2007. Lead exposure and cardiovascular disease - a systematic review. Environmental Health Perspectives, 115(3), pp.472-482.

Neprash, H. T., A. Zink, J. Gray, and K. Hempstead. 2018. Chronic Care, Prescription Drugs \& More Physicians' Participation in Medicaid Increased Only Slightly Following Expansion. Health Affairs 37(7): 1087-1091

Nikpay, S., S. Freedman, H. Levy, and T. Buchmueller. 2017. Effect of the Affordable Care Act Medicaid Expansion on Emergency Department Visits: Evidence from State-Level Emergency Department Databases. Annals of Emergency Medicine 70(2): 215-225.

Oster, E. 2018. Diabetes and Diet: Purchasing Behavior Change in Response to Health Information. American Economic Journal: Applied Economics, 10(4): 308-48.

Paustian, M. L., J. A. Alexander, D. K. El Reda, C. G. Wise, L. A. Green, and M. D. Fetters. 2014. Partial and Incremental PCMH Practice Transformation: Implications for Quality and Costs. Health Service Research 49: 52-74.

Pickens, G. et al. 2019. Changes in Hospital Service Demand, Cost, and Patient Illness Severity Following Health Reform. Health Services Research 54(4):739-751.

Pitts, S. R., E. R. Carrier, E. C. Rich, and A. L. Kellermann. 2010. Where Americans Get Acute Care: Increasingly, It's Not at Their Doctor's Office. Health Affairs 29(9):1620-9.

Polsky, D., M. Richards, S. Basseyn, D. Wissoker, G. M. Kenney, S. Zuckerman, and K. V. Rhodes. 2015. Appointment Availability after Increases in Medicaid Payments for Primary Care. New England Journal of Medicine 372: 537-545

Sharma, A., S. Dresden, E. Powell, R. Kang, and J. Feinglass. 2017. Emergency Department Visits and Hospitalizations for the Uninsured in Illinois Before and After Affordable Care Act Insurance Expansion. Journal of Community Health 42(3): 591-59

Sommers, B. D., B. Maylone, R. J. Blendon, E. J. Orav, and A. M. Epstein. 2017. Three-Year Impacts of The Affordable Care Act: Improved Medical Care And Health Among Low Income Adults. Health Affairs 36(6):1119-1128.

Sommers, B., R. Blendon, E. J. Orav, and A. Epstein. 2016. Changes in Utilization and Health Among Low-Income Adults After Medicaid Expansion or Expanded Private Insurance. Journal of the American Medical Association 176(10): 1501-1509.

Sommers, B.D. and K. I. Simon. 2017. Health insurance and emergency department use-a complex relationship. $N$ Engl J Med, 376(18), p.1708. 
Starfield B., and L. Shi. 2004. The Medical Home, Access to Care, and Insurance: A Review of Evidence. Pediatrics 113: 1493-1498.

Taubman, S. L., H. L. Allen, B. J. Wright, K. Baicker, and A. N. Finkelstein. 2014. Medicaid Increases Emergency-Department Use: Evidence from Oregon's Health Insurance Experiment. Science 343(6186): 263-268.

Téllez-Rojo, M.M., Bellinger, D.C., Arroyo-Quiroz, C., Lamadrid-Figueroa, H., MercadoGarcia, A., Schnaas-Arrieta, L., Wright, R.O., Hérnandez-Avila, M. and H. Hu. 2006. Longitudinal associations between blood lead concentrations lower than $10 \mu \mathrm{g} / \mathrm{dL}$ and neurobehavioral development in environmentally exposed children in Mexico City. Pediatrics, 118(2), pp.e323-e330.

Urban, N. 2018. Beyond the Water: Lead Exposure in Michigan's Children. Data Driven Detroit. Accessed: 11/11/2019. https://datadrivendetroit.org/blog/2018/12/19/lead-exposure-in$\underline{\text { michigans-children/ }}$

Wang, R., X. Chen, and X. Li. 2019. Something in the Pipe: Flint Water Crisis and Health at Birth. IZA DP No. 12115.

Xu, K. T. 2002. Usual Source of Care in Preventive Service Use: A Regular Doctor versus a Regular Site. Health Service Research. 37(6): 1509-1529.

Zahran, S., S. P. McElmurry, and R. C. Sadler. 2017. Four Phases of the Flint Water Crisis: Evidence from Blood Lead Levels in Children. Environmental Research 157: 160-172.

Zhu M., E. F. Fitzgerald, K. H. Gelberg, S. Lin, and C. M. Druschel. 2010. Maternal Low-Level Lead Exposure and Fetal Growth. Environmental Health Perspectives 118: 1471-1475. 
Table 1: Summary Statistics

Panel A: Demographics and Primary Outcomes

\begin{tabular}{|c|c|c|c|c|c|}
\hline & \multicolumn{2}{|c|}{ Before } & \multicolumn{2}{|c|}{ After } & \multirow{2}{*}{$\begin{array}{c}\text { Difference-in- } \\
\text { Differences }\end{array}$} \\
\hline & Flint & Other & Flint & Other & \\
\hline Female & 0.483 & 0.493 & 0.489 & 0.494 & $0.005^{*}$ \\
\hline Black & 0.610 & 0.533 & 0.617 & 0.536 & 0.0036 \\
\hline \multirow[t]{2}{*}{ Maternal Age } & 24.61 & 26.08 & 24.64 & 26.24 & $-0.1255^{* * *}$ \\
\hline & $(5.29)$ & $(5.81)$ & $(5.20)$ & $(5.81)$ & \\
\hline Any Lead Test & 0.030 & 0.029 & 0.055 & 0.038 & $0.016 * * *$ \\
\hline Any Office Visit & 0.388 & 0.281 & 0.296 & 0.198 & $-0.008 * * *$ \\
\hline Any ED Visit & 0.104 & 0.091 & 0.091 & 0.082 & $-0.0037 * *$ \\
\hline \multirow[t]{2}{*}{ \# of Claims } & 3.814 & 3.766 & 2.335 & 2.305 & -0.0177 \\
\hline & $(9.53)$ & $(8.41)$ & $(6.40)$ & $(5.81)$ & \\
\hline \multirow[t]{2}{*}{ Payment } & 825.8 & 803.6 & 316.8 & 248.1 & 10.43 \\
\hline & (3463.8) & $(3447.4)$ & $(1777.3)$ & $(1985.1)$ & \\
\hline Person Months & 58927 & 762858 & 56549 & 751713 & \\
\hline Persons & 3699 & 51091 & 3913 & 53914 & \\
\hline
\end{tabular}

Panel B: Per Capita Emergency Department Visits by Type

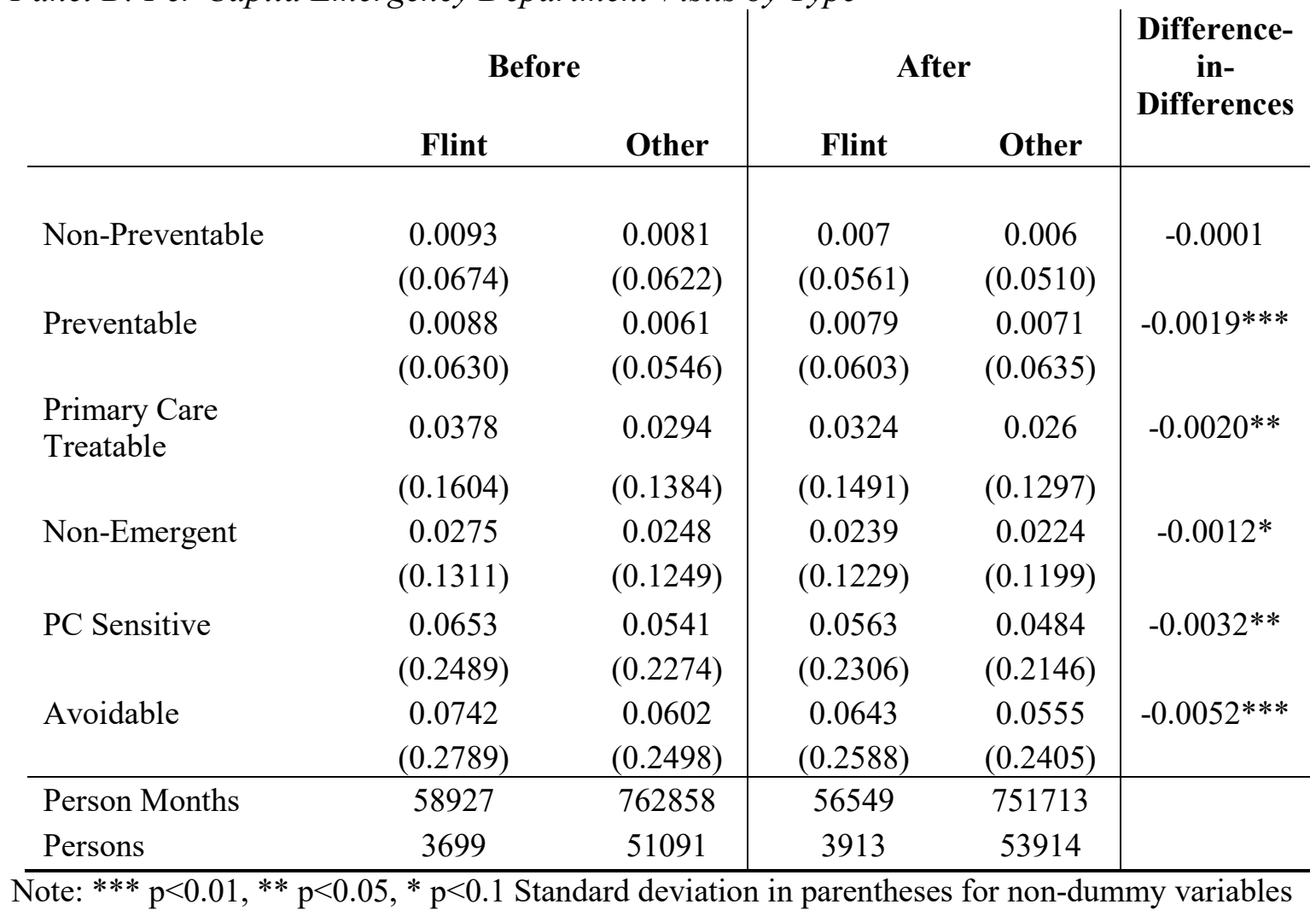


Table 2: Individual-Level Difference-in-Differences Results for all Enrolled Children

\begin{tabular}{lcccccc}
\hline & $(1)$ & $(2)$ & $(3)$ & $(4)$ & $(5)$ & $(6)$ \\
& $\begin{array}{c}\text { Lead } \\
\text { Claims }\end{array}$ & $\begin{array}{c}\text { Office } \\
\text { Visits }\end{array}$ & Vaccines & ED Visits & Claims & Payment \\
& & & & & & \\
\hline & & & & & & \\
Panel A: Any & $0.017^{* * *}$ & -0.003 & 0.005 & $-0.003^{*}$ & $0.018^{* * *}$ & $0.017^{* * *}$ \\
Flint*After & $(0.001)$ & $(0.006)$ & $(0.003)$ & $(0.002)$ & $(0.004)$ & $(0.004)$ \\
& {$[0.00]$} & {$[0.49]$} & {$[0.04]$} & {$[0.15]$} & {$[0.00]$} & {$[0.00]$} \\
& 0.004 & 0.074 & 0.028 & 0.012 & 0.091 & 0.091 \\
R-squared & 0.035 & 0.249 & 0.064 & 0.088 & 0.461 & 0.46 \\
Dependent Variable & & & & & & \\
Mean & $0.017 * * *$ & -0.027 & $0.013 * * *$ & 0.0010 & $0.073 * *$ & $12.130^{*}$ \\
& $(0.001)$ & $(0.036)$ & $(0.004)$ & $(0.002)$ & $(0.032)$ & $(6.646)$ \\
Panel B: Number per Capita & {$[0.00]$} & {$[0.40]$} & {$[0.00]$} & {$[0.81]$} & {$[0.02]$} & {$[0.18]$} \\
Flint*After & 0.004 & 0.046 & 0.019 & 0.007 & 0.042 & 0.059 \\
& 0.039 & 1.058 & 0.083 & 0.138 & 3.067 & 349.042 \\
R-squared & & & & & & \\
Dependent Variable & $1,618,450$ & $1,618,450$ & $1,618,450$ & $1,618,450$ & $1,618,450$ & $1,618,450$ \\
Mean & 61,511 & 61,511 & 61,511 & 61,511 & 61,511 & 61,511 \\
& 16 & 16 & 16 & 16 & 16 & 16 \\
Obs. & & & & & &
\end{tabular}

Notes: Regressions are at the enrollee-month level for all eligible, enrolled children. Treated city is Flint. Control cities are Ann Arbor, Dearborn, Detroit, Farmington Hills, Grand Rapids, Kalamazoo, Lansing, Livonia, Rochester Hills, Southfield, Sterling Heights, Troy, Warren, Westland, and Wyoming. Each coefficient is from a separate regression. All regressions include fixed effects for city, claim year, claim month, birth year, and birth month. Total payment is trimmed to exclude the top 1\%. Robust standard errors are clustered at the city level. Brackets contain wild bootstrapped $p$ values.

$* * * \mathrm{p}<0.01, * * \mathrm{p}<0.05, * \mathrm{p}<0.1$ 
Table 3: Changes in Per Capita ED Visits by Type

\begin{tabular}{lcccccc}
\hline & $(1)$ & $(2)$ & $(3)$ & $(4)$ & $(5)$ & $(6)$ \\
& $\begin{array}{c}\text { Non- } \\
\text { Preventable }\end{array}$ & Preventable & $\begin{array}{c}\text { Primary } \\
\text { Care } \\
\text { Treatable }\end{array}$ & $\begin{array}{c}\text { Non- } \\
\text { Emergent }\end{array}$ & $\begin{array}{c}\text { PC } \\
\text { Sensitive }\end{array}$ & Avoidable \\
\hline Flint*After & & & & & & \\
& -0.00001 & $-0.0020^{* * *}$ & $-0.0019^{*}$ & $-0.0011^{* *}$ & $-0.0030^{* *}$ & $-0.0049^{* * *}$ \\
R-squared & $(0.0003)$ & $(0.0002)$ & $(0.0009)$ & $(0.0005)$ & $(0.0010)$ & $(0.0009)$ \\
Obs. & {$[1.00]$} & {$[0.01]$} & {$[0.28]$} & {$[0.01]$} & {$[0.06]$} & {$[0.01]$} \\
Number of enrollees & 0.004 & 0.003 & 0.008 & 0.006 & 0.01 & 0.01 \\
Number of Cities & $1,618,450$ & $1,618,450$ & $1,618,450$ & $1,618,450$ & $1,618,450$ & $1,618,450$ \\
Dependent Variable & 1,511 & 61,511 & 61,511 & 61,511 & 61,511 & 61,511 \\
Mean & 0.0072 & 0.0068 & 0.0284 & 0.024 & 0.0524 & 0.0592 \\
\hline
\end{tabular}

Notes: Primary Care (PC) Sensitive visits include PC Treatable and Non-Emergent. Avoidable visits include Preventable, PC Treatable, and Non-Emergent. Regressions are at the enrollee-month level for all eligible, enrolled children. Treated city is Flint. Control cities are Ann Arbor, Dearborn, Detroit, Farmington Hills, Grand Rapids, Kalamazoo, Lansing, Livonia, Rochester Hills, Southfield, Sterling Heights, Troy, Warren, Westland, and Wyoming. Each coefficient is from a separate regression. All regressions include fixed effects for city, claim year, claim month, birth year, and birth month. Robust standard errors are clustered at the city level. Brackets contain wild bootstrapped $p$ values. ${ }^{* * *} \mathrm{p}<0.01,{ }^{* *}$ $\mathrm{p}<0.05, * \mathrm{p}<0.1$ 
Table 4: Separate Coefficients Estimated for Each Post-Period Quarter

Panel A: Individual-Level Difference-in-Differences Results for all Enrolled Children

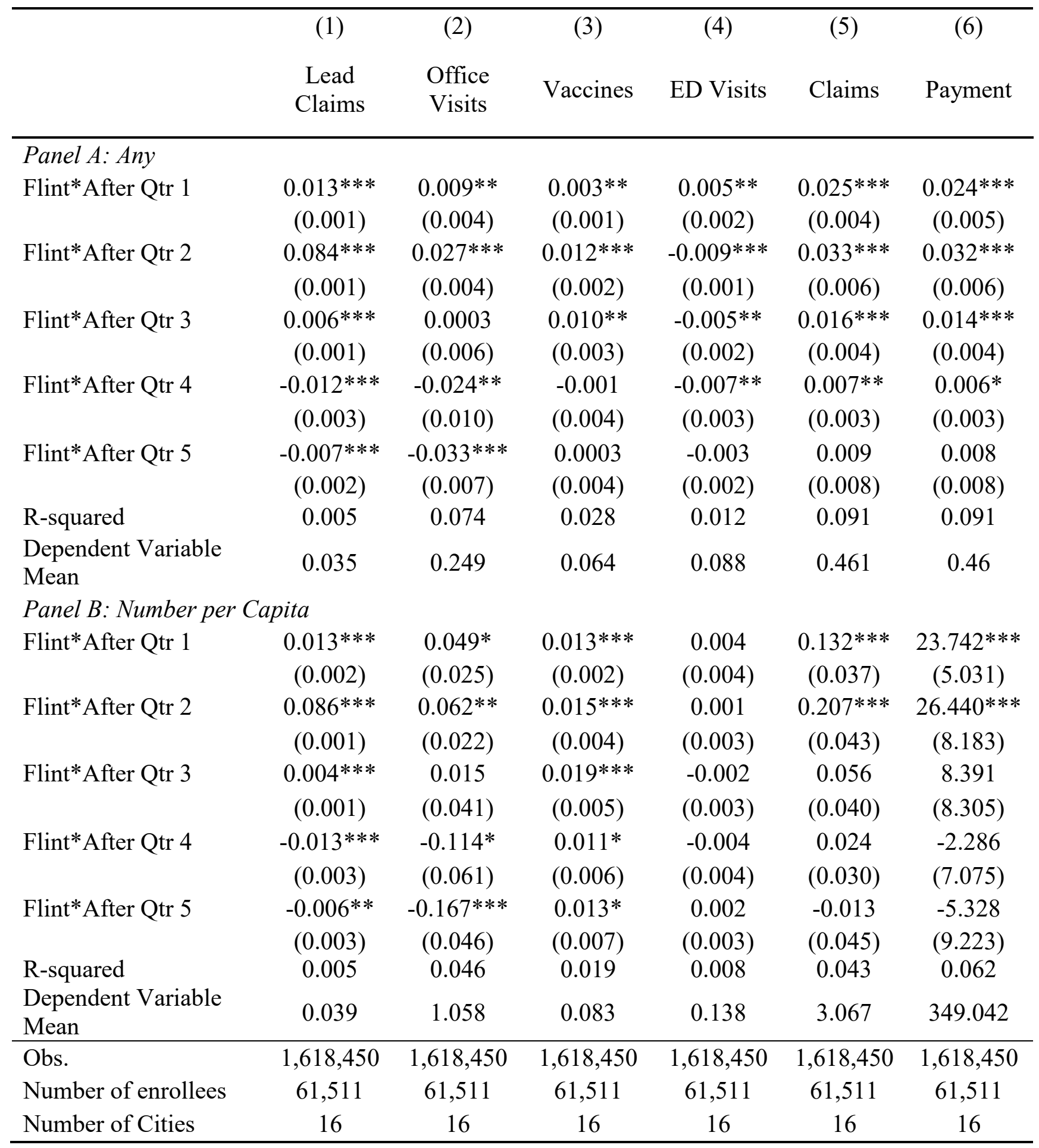


Notes: Regressions are at the enrollee-month level for all eligible, enrolled children. Treated city is Flint. Each column is from a separate regression. All regressions include fixed effects for city, claim year, claim month, birth year, and birth month. Robust standard errors are clustered at the city level. *** $\mathrm{p}<0.01,{ }^{* *}$ $\mathrm{p}<0.05, * \mathrm{p}<0.1$

Panel C: Changes in Per Capita ED Visits by Type

\begin{tabular}{|c|c|c|c|c|c|c|}
\hline & $\begin{array}{c}(1) \\
\text { Non- } \\
\text { Preventable }\end{array}$ & $\begin{array}{c}\text { (2) } \\
\text { Preventable }\end{array}$ & $\begin{array}{c}(3) \\
\text { Primary } \\
\text { Care } \\
\text { Treatable } \\
\end{array}$ & $\begin{array}{c}(4) \\
\text { Non- } \\
\text { Emergent }\end{array}$ & $\begin{array}{c}(5) \\
\text { PC } \\
\text { Sensitive }\end{array}$ & $\begin{array}{c}\text { (6) } \\
\text { Avoidable }\end{array}$ \\
\hline Flint*After Qtr 1 & $\begin{array}{l}0.0011^{*} \\
(0.0006)\end{array}$ & $\begin{array}{c}-0.0008^{* * *} \\
(0.0003)\end{array}$ & $\begin{array}{c}0.0004 \\
(0.0010)\end{array}$ & $\begin{array}{c}0.0022^{* *} \\
(0.0009)\end{array}$ & $\begin{array}{c}0.0025 \\
(0.0017)\end{array}$ & $\begin{array}{c}0.0017 \\
(0.0016)\end{array}$ \\
\hline Flint*After Qtr 2 & $\begin{array}{c}0.0004^{* * *} \\
(0.0001)\end{array}$ & $\begin{array}{l}-0.0004 \\
(0.0003)\end{array}$ & $\begin{array}{c}-0.0014 * \\
(0.0007)\end{array}$ & $\begin{array}{c}-0.0027^{* * *} \\
(0.0008)\end{array}$ & $\begin{array}{c}-0.0040 * * * \\
(0.0010)\end{array}$ & $\begin{array}{c}-0.0045^{* * *} \\
(0.0011)\end{array}$ \\
\hline Flint*After Qtr 3 & $\begin{array}{l}-0.0002 \\
(0.0003)\end{array}$ & $\begin{array}{c}-0.0023 * * * \\
(0.0001)\end{array}$ & $\begin{array}{l}-0.0006 \\
(0.0007)\end{array}$ & $\begin{array}{c}-0.0028 * * * \\
(0.0007)\end{array}$ & $\begin{array}{c}-0.0034 * * * \\
(0.0009)\end{array}$ & $\begin{array}{c}-0.0057 * * * \\
(0.0009)\end{array}$ \\
\hline Flint*After Qtr 4 & $\begin{array}{l}-0.0008 \\
(0.0005)\end{array}$ & $\begin{array}{c}-0.0030 * * * \\
(0.0004)\end{array}$ & $\begin{array}{c}-0.0042 * * * \\
(0.0014)\end{array}$ & $\begin{array}{c}-0.0027 * * * \\
(0.0005)\end{array}$ & $\begin{array}{c}-0.0069 * * * \\
(0.0017)\end{array}$ & $\begin{array}{c}-0.0099 * * * \\
(0.0020)\end{array}$ \\
\hline Flint*After Qtr 5 & $\begin{array}{c}0.0001 \\
(0.0004)\end{array}$ & $\begin{array}{c}-0.0029 * * * \\
(0.0007)\end{array}$ & $\begin{array}{l}-0.0016^{*} \\
(0.0008) \\
\end{array}$ & $\begin{array}{c}0.0004 \\
(0.0009) \\
\end{array}$ & $\begin{array}{l}-0.0012 \\
(0.0013)\end{array}$ & $\begin{array}{c}-0.0041 * * * \\
(0.0013)\end{array}$ \\
\hline $\mathrm{R}$-squared & 0.004 & 0.003 & 0.008 & 0.006 & 0.01 & 0.01 \\
\hline Obs. & $1,618,450$ & $1,618,450$ & $1,618,450$ & $1,618,450$ & $1,618,450$ & $1,618,450$ \\
\hline $\begin{array}{l}\text { Number of } \\
\text { enrollees }\end{array}$ & 61,511 & 61,511 & 61,511 & 61,511 & 61,511 & 61,511 \\
\hline Number of Cities & 16 & 16 & 16 & 16 & 16 & 16 \\
\hline $\begin{array}{l}\text { Dependent } \\
\text { Variable Mean }\end{array}$ & 0.007 & 0.007 & 0.028 & 0.024 & 0.052 & 0.059 \\
\hline
\end{tabular}

Notes: Primary Care (PC) Sensitive visits include PC Treatable and Non-Emergent. Avoidable visits include Preventable, PC Treatable, and Non-Emergent. Regressions are at the enrollee-month level for all eligible, enrolled children. Treated city is Flint. Control cities are Ann Arbor, Dearborn, Detroit, Farmington Hills, Grand Rapids, Kalamazoo, Lansing, Livonia, Rochester Hills, Southfield, Sterling Heights, Troy, Warren, Westland, and Wyoming. Each column is from a separate regression. All regressions include fixed effects for city, claim year, claim month, birth year, and birth month. Robust standard errors are clustered at the city level. $* * * \mathrm{p}<0.01, * * \mathrm{p}<0.05, * \mathrm{p}<0.1$ 
Table 5: Top CCS Categories for Avoidable Claims in the ED

\begin{tabular}{clc} 
CCS & Description & \% of Claims \\
\hline 126 & Upper Respiratory Infection (URI) & 48.51 \\
133 & Lower Respiratory Infection (LRI) & 10.83 \\
197 & Skin and Subcutaneous Tissue Infection & 7.16 \\
128 & Asthma & 6.81 \\
251 & Abdominal Pain & 3.65 \\
83 & Epilepsy, convulsions & 3.82 \\
222 & Hemolytic Jaundice and Perinatal Jaundice & 1.74 \\
140 & Gastritis and Duodenitis & 1.39 \\
107 & Cardiac Arrest and Ventricular Fibrillation & 1.28 \\
125 & Acute Bronchitis & 1.25 \\
\hline \hline
\end{tabular}

Notes: Top 10 most frequently occurring CCS categories in claims for care identified as avoidable by the NYU Algorithm taking place in the ED prior to September 2015. 
Table 6: Effect Comparison of Substitution Between Office Visits and Avoidable ED Visits by Category of Care

\begin{tabular}{lcccc|c|c} 
Description & \multicolumn{2}{c}{ Any Office Visits } & \multicolumn{2}{c}{ Avoidable ED Visits } & \multicolumn{2}{c}{ Ho } \\
& Coeff & Std. Err & Coeff. & Std. Err & Chi2 & p $>$ Chi2 \\
\hline All & 0.027 & 0.004 & -0.003 & 0.001 & 0.020 & 0.886 \\
Upper Respiratory Infection (URI) & 0.017 & 0.008 & -0.044 & 0.014 & 0.030 & 0.852 \\
Lower Respiratory Infection (LRI) & -0.027 & 0.012 & 0.007 & 0.016 & 0.050 & 0.831 \\
Skin and Subcutaneous Tissue & & & & & \\
Infection & 0.086 & 0.015 & -0.036 & 0.012 & 0.220 & 0.636 \\
Asthma & 0.002 & 0.016 & -0.031 & 0.014 & 0.020 \\
Abdominal Pain & 0.168 & 0.027 & -0.086 & 0.024 & 0.110 & 0.877 \\
Epilepsy, convulsions & -0.078 & 0.018 & -0.001 & 0.020 & 0.060 & 0.743 \\
Jaundice & 0.058 & 0.024 & -0.007 & 0.003 & 0.280 & 0.811 \\
Gastritis and Duodenitis & 0.100 & 0.024 & -0.095 & 0.008 & 0.000 & 0.596 \\
Acute Bronchitis & -0.020 & 0.010 & -0.003 & 0.005 & 0.020 & 0.968 \\
\hline \hline
\end{tabular}

Note: $\mathrm{H}_{0}: \beta_{\text {OfficeVisits }}=-\beta_{\text {AvoidableEDVisits. }}$ Each estimate comes from a separate regression at the enrollee-month level for all children with claims in the specified CCS category. Treated city is Flint. Control cities are Ann Arbor, Dearborn, Detroit, Farmington Hills, Grand Rapids, Kalamazoo, Lansing, Livonia, Rochester Hills, Southfield, Sterling Heights, Troy, Warren, Westland, and Wyoming. All regressions include fixed effects for city, claim year, claim month, birth year, and birth month. Robust standard errors are clustered at the city level. 
Table 7: Use of Primary Care Following Lead Testing

\begin{tabular}{|c|c|c|c|c|}
\hline & $\begin{array}{c}\text { (1) } \\
\text { Immunization }\end{array}$ & $\begin{array}{r}(2) \\
\text { Well } \\
\end{array}$ & $\begin{array}{c}(3) \\
\text { Same } \\
\text { Provider }\end{array}$ & $\begin{array}{l}(4) \\
\text { Same } \\
\text { Clinic } \\
\end{array}$ \\
\hline Flint*After & $\begin{array}{l}0.0367 * \\
(0.0148)\end{array}$ & $\begin{array}{c}0.0294 * * * \\
(0.0050)\end{array}$ & $\begin{array}{c}0.0802 * * \\
(0.0231)\end{array}$ & $\begin{array}{c}0.1480 * * * \\
(0.0295)\end{array}$ \\
\hline R-squared & 0.0252 & 0.0242 & 0.24 & 0.3463 \\
\hline Obs. & 21,413 & 21,413 & 16,820 & 16,820 \\
\hline $\begin{array}{l}\text { Number of Cities } \\
\text { Dependent Variable }\end{array}$ & 16 & 16 & 16 & 16 \\
\hline Mean & 0.1668 & 0.2004 & 0.5383 & 0.6272 \\
\hline
\end{tabular}

Note: Each column shows estimates for specification for care received within 91 days of a lead test. The dependent variables are: Immunization - immunization as primary reason for visit (CCS code 10); Well well child visit (CCS code 255 and 256); Same provider - provider seen was the same (National Provider Identifier) as the one administering the lead test; Same clinic - clinic was the same (National Biller Identifier) as in the one billing for the lead test. Specifications (1)-(4) limit observations to visits within 91 days of administration of lead test. Treated city is Flint. Control cities are Ann Arbor, Dearborn, Detroit, Farmington Hills, Grand Rapids, Kalamazoo, Lansing, Livonia, Rochester Hills, Southfield, Sterling Heights, Troy, Warren, Westland, and Wyoming. All regressions control for female, maternal race, and education, and include fixed effects for city, month, year, birth year, and birth month. Robust standard errors are clustered at the city level. $* * * \mathrm{p}<0.01, * * \mathrm{p}<0.05, * \mathrm{p}<0.1$ 
Figure 1: Number of Lead Tests in Flint Compared to Control Cities

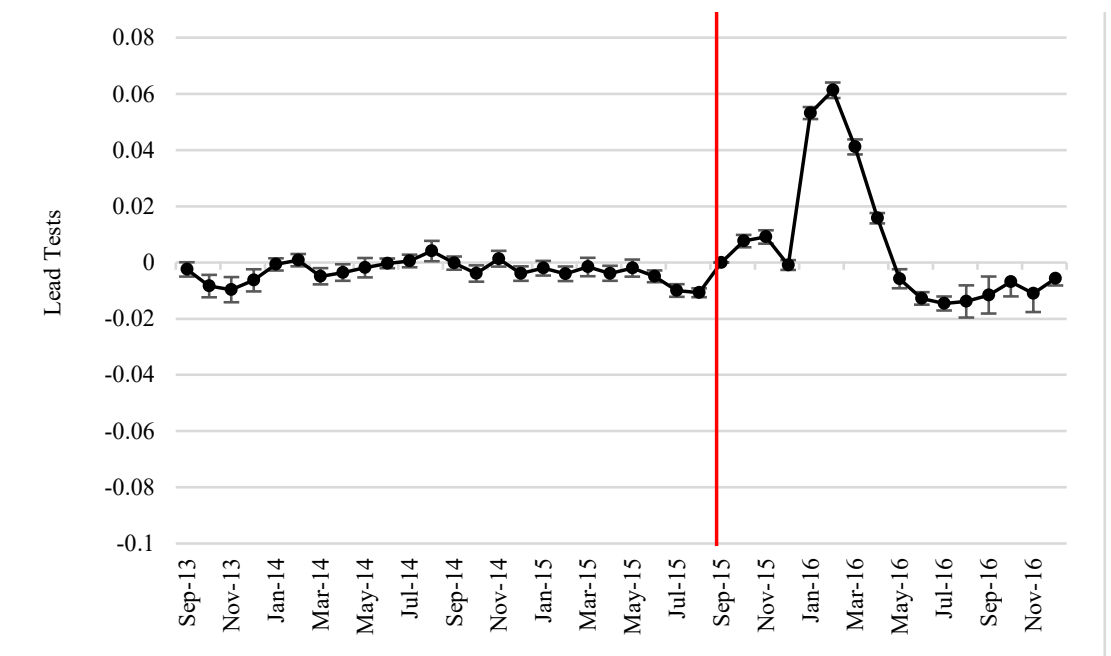


Figure 2: Quarterly Difference-in-Differences Effects on Office Visits, Avoidable ED Visits, and Payments

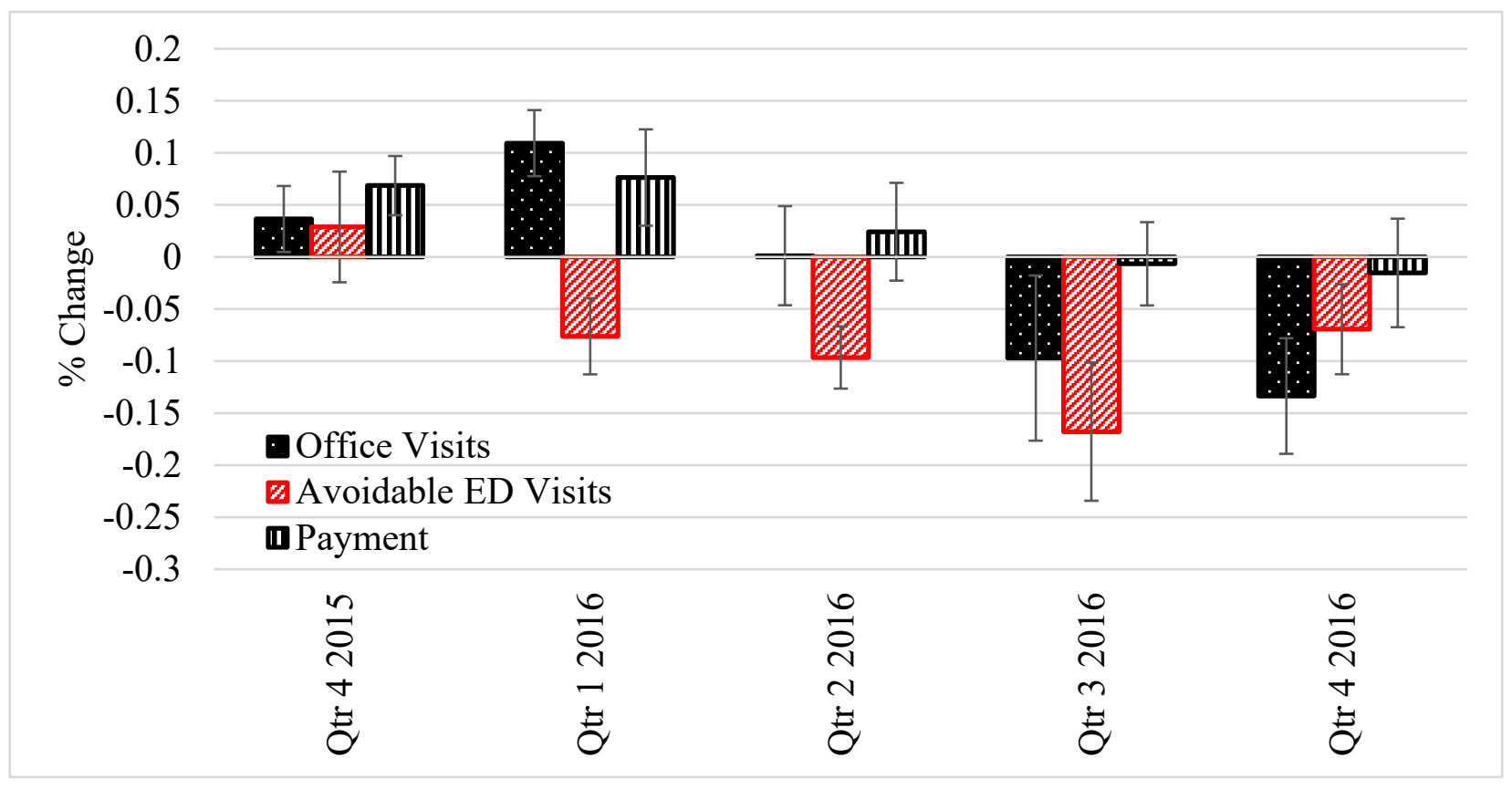

Notes: Effects from regressions for any office visits, avoidable ED visits, and payments at the enrolleemonth level for all eligible, enrolled children. Avoidable visits include Preventable, PC Treatable, and NonEmergent. Treated city is Flint. Control cities are Ann Arbor, Dearborn, Detroit, Farmington Hills, Grand Rapids, Kalamazoo, Lansing, Livonia, Rochester Hills, Southfield, Sterling Heights, Troy, Warren, Westland, and Wyoming. Each set of effects for an outcome is from a separate regression. All regressions include child and maternal characteristics and fixed effects for city, claim year, claim month, birth year, and birth month. Robust standard errors are clustered at the city level. 
Figure 3: Changes in Outcome by Diagnosis Classification

Panel A: Any Office Visits

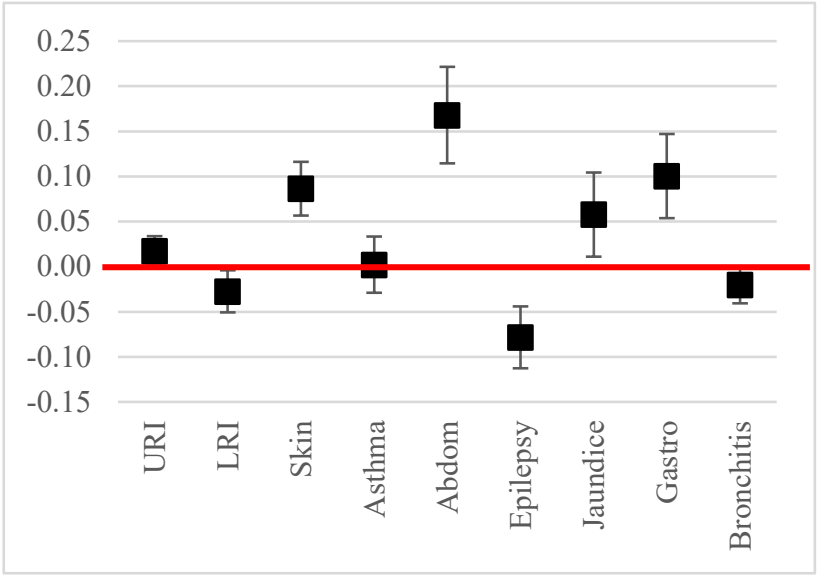

\section{Panel B: Per Capita Avoidable ED Visits}

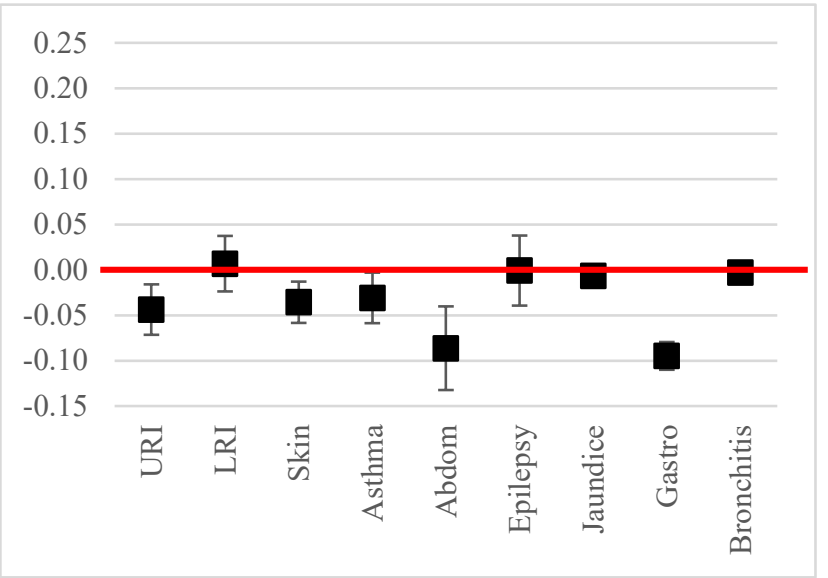

Panel C: Any Office Visits vs. Avoidable ED Visits

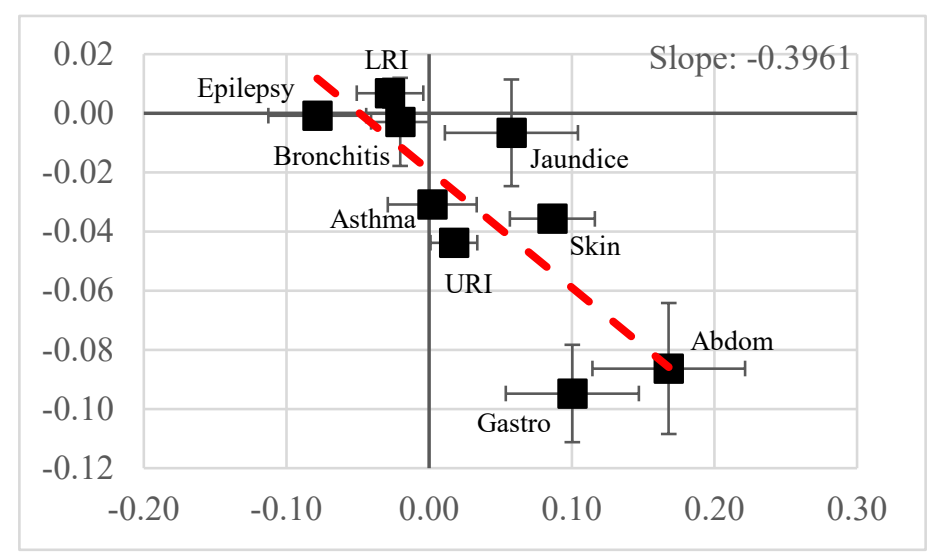

Notes: Each point is the coefficient estimate of a separate specification at the enrollee-month level for all children with claims in the specified CCS category. Treated city is Flint. All regressions include fixed effects for city, claim year, claim month, birth year, and birth month. Robust standard errors are clustered at the city level. Whiskers show a 95\% confidence interval. Panel C plots any office visit on the y-axis and per capita avoidable ED visits on the $\mathrm{x}$-axis from panels $\mathrm{A}$ and $\mathrm{B}$. 


\section{Figure 4: Adjusted Monthly Differences by Outcome}

\section{Panel A: Number of Claims}

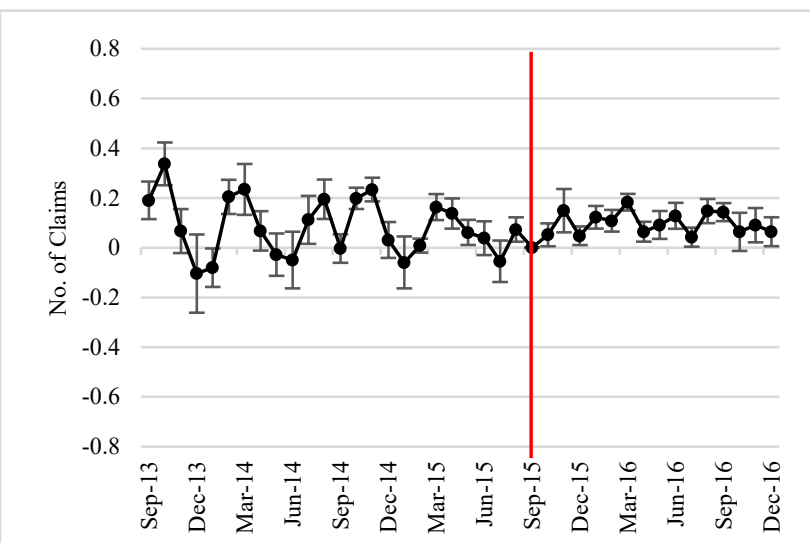

Panel B: Any Office Visits

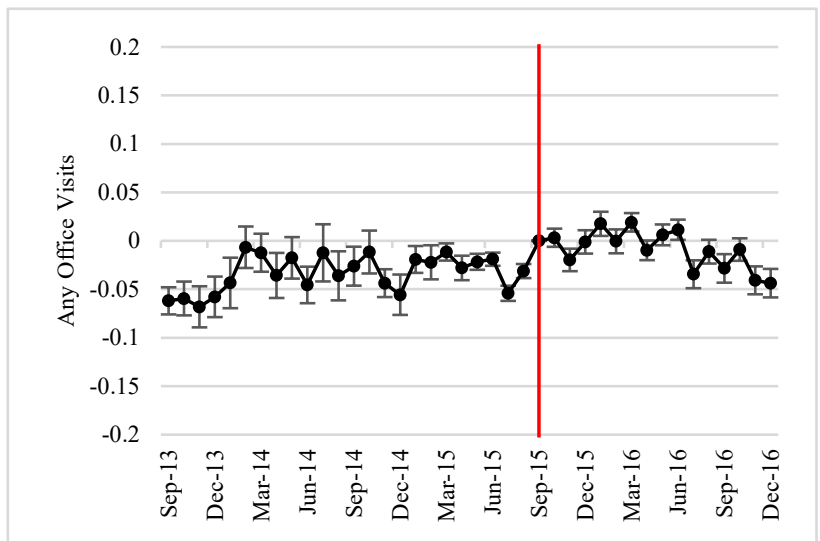

Panel C: Preventable ED visit

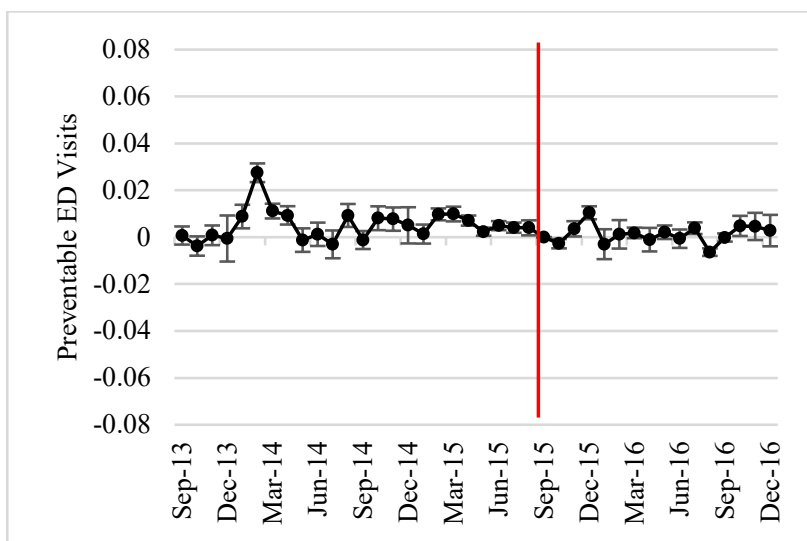

Notes: Each graph represents estimation results from a separate specification. Each point represents the monthly difference between treated and control, adjusted for gender, maternal race, and maternal education. Treated city is Flint. Control cities are Ann Arbor, Dearborn, Detroit, Farmington Hills, Grand Rapids, Kalamazoo, Lansing, Livonia, Rochester Hills, Southfield, Sterling Heights, Troy, Warren, Westland, and Wyoming. All regressions include fixed effects for city, birth year, and birth month. Robust standard errors are clustered at the city level. Whiskers show a $95 \%$ confidence interval. 


\section{Figure 5: Quarterly Difference-in-Differences Effects on Office Visits and Avoidable ED Visits through 2017}

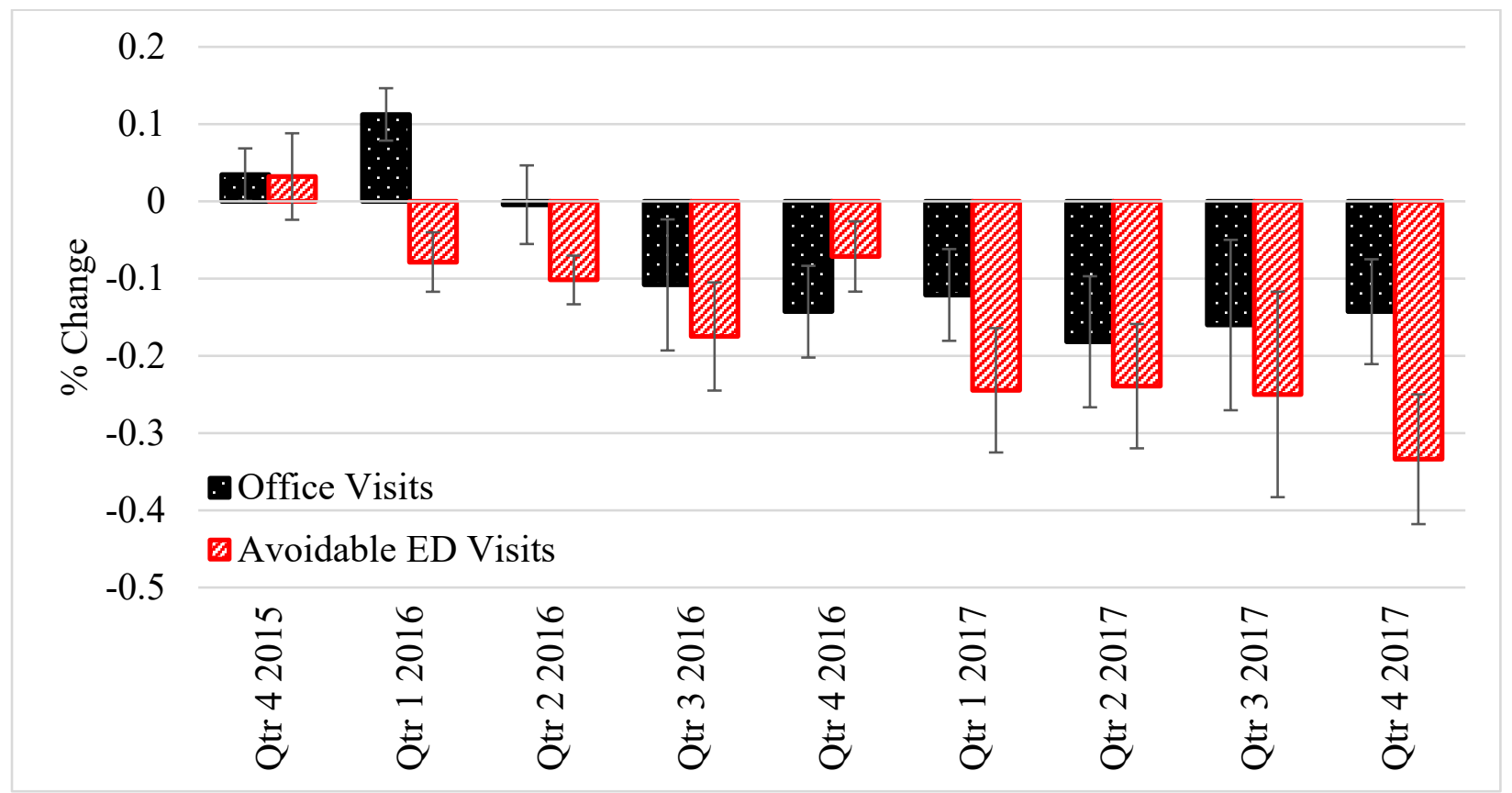

Notes: Effects are from regressions for any office visits, avoidable ED visits, and payments at the enrolleemonth level for all eligible, enrolled children. Avoidable visits include Preventable, PC Treatable, and NonEmergent. Treated city is Flint. Control cities are Ann Arbor, Dearborn, Detroit, Farmington Hills, Grand Rapids, Kalamazoo, Lansing, Livonia, Rochester Hills, Southfield, Sterling Heights, Troy, Warren, Westland, and Wyoming. Each set of effects for an outcome is from a separate regression. All regressions include child and maternal characteristics and fixed effects for city, claim year, claim month, birth year, and birth month. Robust standard errors are clustered at the city level. 
Appendix A. Background on Flint (adapted from Grossman and Slusky, 2019)

Until 1967, Flint used the Flint River as its water source. The city had shortage concerns given its expanding population (Carmody, 2016), and so began drawing water from Lake Huron through the Detroit Water and Sewerage Deparment (DWSD). In 2011, the Governor of Michigan appointed an Emergency Manager to make fiscal decisions for the city, given its precarious economic health (Longley, 2011). At this time, DWSD water rates were rising (Zahran, et al., 2017). To avoid these higher rates, the Emergency Manager explored building a pipeline directly to Lake Huron (City of Flint, 2015; Walsh, 2014). However, the project would take more than two years to complete. In the interim, Flint would use water from the Flint River (beginning in April 2014), while Genesee County continued to work with the DWSD (Carmody, 2016).

Flint had to treat the new water source, but it did not use anti-corrosive inhibitors (Pieper et al., 2017; Olson et al., 2017). Flint citizens were concerned about the appearance and odor of the water but were repeatedly assured that it was safe to drink (City of Flint, 2015a,b). While the city issued multiple boil advisories due to a positive fecal coliform tests and an EPA violation for excess trihalomethanes (TTHM) in the water (Fonger, 2014a, 2014b; Adams, 2014), Flint consistently reassured citizens the water was safe and that any issues would be fixed soon (City of Flint, 2015a,b).

In the summer of 2015, a team led by Mark Edwards began independently testing Flint's water and in August reported much higher levels of lead than previously reported, due to extremely corrosive water. ${ }^{31}$ In September 2015, Mona Hanna-Attish, a Flint pediatrician, reported a substantial increase in children's blood lead levels (Fonger, 2015c; Hanna-Attish et al., 2016). This finally led the city to switch back to Lake Huron water on October 16, 2015 (Emery, 2015).

\section{References}

Adams, D. (2014). Flint officials say 'abnormal' test to blame in E. coli scare, water boil advisory remains. Mlive.com, August 18, 2014. Available at: http://www.mlive.com/news/flint/index.ssf/2014/08/flint_officials_say_abnormal_t.html.

Carmody, T. (2016). How the Flint River got so toxic: Factories and people have been dumping sewage, chemicals, and road salt in the Flint River for more than a century. The Verge. https://www.theverge.com/2016/2/26/11117022/flint-michigan-water-crisis-leadpollution-history

City of Flint: Water System Questions \& Answers. (2015). January 13, 2015 Available at: https://www.cityofflint.com/wp-content/uploads/CoF-Water-System-QA.pdf.

City of Flint: Water System Update with Questions \& Answers. (2015). February 16, 2015 Available at: https://www.cityofflint.com/wp-content/uploads/Water-Sysytem-FAQUpdate-2-16-151.pdf.

${ }^{31} \mathrm{http} / / /$ flintwaterstudy.org/wp-content/uploads/2015/10/Flint-Corrosion-Presentation-final.pdf 
Emery, A. (2015). Flint Reconnects to Detroit Water, may take 3 weeks to clear all pipes. Mlive.com, October 16, 2015. Available at: http://www.mlive.com/news/flint/index.ssf/2015/10/flint_reconnecting_to_detroit.html.

Fonger R. (2014a.) Tests positive for total coliform again in water-boil area on Flint's west side. Mlive.com, August 19, 2014. Available at: http://www.mlive.com/news/flint/index.ssf/2014/08/water_boil_area_in_flint_gets.html.

Fonger, R. (2014b). Flint issues boil water advisory for section of the city after positive test for total coliform bacteria. Mlive.com, September 5, 2014. Available at: http://www.mlive.com/news/flint/index.ssf/2014/09/flint_issues_boil_water_adviso.html.

Longley, K. (2011). Emergency Manager Michael Brown appointed to lead Flint through second state takeover. Mlive.com, November 29, 2011. Available at: http://www.mlive.com/news/flint/index.ssf/2011/11/emergency_manager_michael_brow. html.

Pieper, KJ, M Tang, and MA Edwards. (2017). Flint Water Crisis Caused by Interrupted Corrosion Control: Investigating "Ground Zero" Home. Environmental Science \& Technology, 51(4): 2007-2014.

Walsh, MW. (2014). Detroit's Plan to Profit on Its Water, by Selling to Its Neighbors, Looks Half Empty. The New York Times, May 26, 2014. Available at: http://www.nytimes.com/2014/05/26/business/detroit-plan-to-profit-on-water-looks-halfempty.html 


\section{Appendix Figure A1: Timeline of Important Events in Flint}

\begin{tabular}{|c|c|c|c|c|c|}
\hline $\begin{array}{l}\text { 1897: } \\
\text { Flint passes } \\
\text { ordinance } \\
\text { that all } \\
\text { connections } \\
\text { with any } \\
\text { water main } \\
\text { be made } \\
\text { with lead } \\
\text { pipes } \\
\text { (Masten et } \\
\text { al., 2016). }\end{array}$ & $\begin{array}{ll}\text { 1967- } & 2 \\
\text { 2014: Flint } & \mathrm{C} \\
\text { receives } & \mathrm{a} \\
\text { water from } & \mathrm{E} \\
\text { Detroit } & \mathrm{N} \\
\text { Water and } & \\
\text { Sewerage } & \\
\text { Department } & \\
\text { (DWSD). } & \end{array}$ & $\begin{array}{ll}\text { 2011: } & \text { 2009-2013: } \\
\text { Governor Water rates } \\
\text { appoints (prices) } \\
\text { Emergencyconsistently } \\
\text { Manager. increase. }\end{array}$ & $\begin{array}{l}\text { March } \\
\text { 2014: Flint } \\
\text { and } \\
\text { Genesee } \\
\text { County } \\
\text { plan own } \\
\text { pipeline to } \\
\text { Lake } \\
\text { Huron. }\end{array}$ & $\begin{array}{l}\text { April 2014: } \\
\text { Flint } \\
\text { changes } \\
\text { water } \\
\text { source to } \\
\text { Flint River; } \\
\text { Genesee } \\
\text { County } \\
\text { stays with } \\
\text { DWSD. }\end{array}$ & $\begin{array}{l}\text { Aug-Sept } \\
\text { 2014: } \\
\text { Positive } \\
\text { test for } \\
\text { fecal } \\
\text { coliform, } \\
\text { first boil } \\
\text { advisory. }\end{array}$ \\
\hline $\begin{array}{l}\text { Oct 2014: } \\
\text { Flint GM } \\
\text { plant } \\
\text { switches } \\
\text { off Flint } \\
\text { water } \\
\text { supply } \\
\text { because } \\
\text { of engine } \\
\text { corrosion. }\end{array}$ & $\begin{array}{l}\text { Jan-Mar 2015: } \\
\text { Emergency } \\
\text { manager } \\
\text { stresses water } \\
\text { is safe, refuses } \\
\text { to return to } \\
\text { DWSD }\end{array}$ & $\begin{array}{l}\text { Jun-Jul 2015: } \\
\text { Dr. Edwards } \\
\text { independently } \\
\text { tests Flint waterpre } \\
\text { lead levels, con } \\
\text { finding it to be ann } \\
19 \text { times more } \\
\text { corrosive than } \\
\text { DWSD. lea } \\
\text { DW }\end{array}$ & $\begin{array}{l}015 \text { : } \\
\text { anna- } \\
\text { holds } \\
\text { ence } \\
\text { acing } \\
\text { blood } \\
\text { vels in } \\
\text { n. }\end{array}$ & $\begin{array}{l}\text { Oct 2015: } \\
\text { Flint stops } \\
\text { receiving } \\
\text { water from } \\
\text { Flint River. }\end{array}$ & $\begin{array}{l}\text { Jan 2016: } \\
\text { Michigan } \\
\text { Governor } \\
\text { apologizes on } \\
\text { national } \\
\text { television. }\end{array}$ \\
\hline
\end{tabular}

Source: Adapted from Grossman and Slusky (2019) 


\section{Appendix B: Stratified Analysis}

Table B1: Sample Limited to Children Born to Black Mothers

Panel A: Individual-Level Difference-in-Differences Results for all Enrolled Children

\begin{tabular}{lcccccc}
\hline & $\begin{array}{c}(1) \\
\text { Any lead } \\
\text { claims }\end{array}$ & $\begin{array}{c}\text { Any office } \\
\text { visit }\end{array}$ & $\begin{array}{c}\text { Any } \\
\text { vaccines }\end{array}$ & $\begin{array}{c}\text { Any ED } \\
\text { visit }\end{array}$ & $\begin{array}{c}(5) \\
\text { \# of } \\
\text { claims }\end{array}$ & $\begin{array}{c}\text { Total } \\
\text { payment }(\$)\end{array}$ \\
\hline Flint*After & $0.017^{* * *}$ & $-0.007^{* *}$ & $0.013^{* * *}$ & $-0.009^{* * *}$ & 0.019 & -14.655 \\
& $(0.001)$ & $(0.003)$ & $(0.002)$ & $(0.001)$ & $(0.026)$ & $(8.571)$ \\
& & & & & & \\
R-squared & 0.005 & 0.049 & 0.023 & 0.007 & 0.041 & 0.059 \\
$\begin{array}{l}\text { Obs. } \\
\text { Number of Cities }\end{array}$ & 876,835 & 876,835 & 876,835 & 876,835 & 876,835 & 866,961 \\
$\begin{array}{l}\text { Dependent } \\
\text { Variable Mean }\end{array}$ & 16 & 16 & 16 & 16 & 16 & 16 \\
\hline
\end{tabular}

Notes: Regressions are at the enrollee-month level for all eligible enrolled children. Treated city is Flint. Control cities are Ann Arbor, Dearborn, Detroit, Farmington Hills, Grand Rapids, Kalamazoo, Lansing, Livonia, Rochester Hills, Southfield, Sterling Heights, Troy, Warren, Westland, and Wyoming. Each coefficient is from a separate regression. All regressions include fixed effects for city, claim year, claim month, birth year, and birth month. Robust standard errors are clustered at the city level. $* * * \mathrm{p}<0.01$, ** $\mathrm{p}<0.05, * \mathrm{p}<0.1$ 
Panel B: Changes in Per Capita ED Visits by Type

\begin{tabular}{|c|c|c|c|c|c|c|}
\hline & $\begin{array}{c}(1) \\
\text { Non- } \\
\text { Preventable }\end{array}$ & $\begin{array}{c}\text { (2) } \\
\text { Preventable }\end{array}$ & $\begin{array}{c}(3) \\
\text { Primary } \\
\text { Care } \\
\text { Treatable } \\
\end{array}$ & $\begin{array}{c}\text { (4) } \\
\text { Non- } \\
\text { Emergent }\end{array}$ & $\begin{array}{c}\text { (5) } \\
\text { PC } \\
\text { Sensitive }\end{array}$ & $\begin{array}{c}\text { (6) } \\
\text { Avoidable }\end{array}$ \\
\hline Flint*After & $\begin{array}{c}-0.0005^{* * *} \\
(0.0001)\end{array}$ & $\begin{array}{c}-0.0031 * * * \\
(0.0001)\end{array}$ & $\begin{array}{c}-0.0021 * * * \\
(0.0003)\end{array}$ & $\begin{array}{c}-0.0039^{* * *} \\
(0.0006)\end{array}$ & $\begin{array}{c}-0.0060^{* * *} \\
(0.0008)\end{array}$ & $\begin{array}{c}-0.0091 * * * \\
(0.0009)\end{array}$ \\
\hline R-squared & 0.004 & 0.002 & 0.005 & 0.004 & 0.006 & 0.005 \\
\hline Obs. & 876,835 & 876,835 & 876,835 & 876,835 & 876,835 & 876,835 \\
\hline $\begin{array}{l}\text { Number of } \\
\text { Cities }\end{array}$ & 16 & 16 & 16 & 16 & 16 & 16 \\
\hline $\begin{array}{l}\text { Dependent } \\
\text { Variable Mean }\end{array}$ & 0.0082 & 0.0089 & 0.0353 & 0.0292 & 0.0645 & 0.0734 \\
\hline
\end{tabular}

Notes: Primary Care (PC) Sensitive visits include PC Treatable and Non-Emergent. Avoidable visits include Preventable, PC Treatable, and Non-Emergent. Regressions are at the enrollee-month level for all eligible, enrolled children. Treated city is Flint. Control cities are Ann Arbor, Dearborn, Detroit, Farmington Hills, Grand Rapids, Kalamazoo, Lansing, Livonia, Rochester Hills, Southfield, Sterling Heights, Troy, Warren, Westland, and Wyoming. Each coefficient is from a separate regression. All regressions include fixed effects for city, claim year, claim month, birth year, and birth month. Robust standard errors are clustered at the city level. *** $\mathrm{p}<0.01,{ }^{*} \mathrm{p}<0.05,{ }^{*} \mathrm{p}<0.1$ 
Table B2: Sample Limited to Children in Fee-for-Service Plans

Panel A: Individual-Level Difference-in-Differences Results for all Enrolled Children

\begin{tabular}{lcccccc}
\hline & $\begin{array}{c}(1) \\
\text { Any lead } \\
\text { claims }\end{array}$ & $\begin{array}{c}\text { Any office } \\
\text { visit }\end{array}$ & $\begin{array}{c}\text { Any } \\
\text { vaccines }\end{array}$ & $\begin{array}{c}\text { Any ED } \\
\text { visit }\end{array}$ & $\begin{array}{c}(5) \\
\text { \# of } \\
\text { claims }\end{array}$ & $\begin{array}{c}\text { Total } \\
\text { payment (\$) }\end{array}$ \\
\hline Flint*After & $\begin{array}{c}0.024^{* *} \\
(0.009)\end{array}$ & $\begin{array}{c}0.095^{* * *} \\
(0.010)\end{array}$ & $\begin{array}{c}0.020^{* * *} \\
(0.005)\end{array}$ & $\begin{array}{c}-0.019 \\
(0.014)\end{array}$ & $\begin{array}{c}0.305^{* * *} \\
(0.104)\end{array}$ & $\begin{array}{c}214.064^{* * *} \\
(18.505)\end{array}$ \\
$\begin{array}{l}\text { R-squared } \\
\text { Obs. }\end{array}$ & 0.039 & 0.099 & 0.029 & 0.037 & 0.008 & 0.057 \\
$\begin{array}{l}\text { Number of Cities } \\
\text { Dependent }\end{array}$ & 170,150 & 170,150 & 170,150 & 170,150 & 170,150 & 166,327 \\
Variable Mean & 16 & 16 & 16 & 16 & 16 & 16 \\
\hline
\end{tabular}

Notes: Regressions are at the enrollee-month level for all eligible, enrolled children. Treated city is Flint. Control cities are Ann Arbor, Dearborn, Detroit, Farmington Hills, Grand Rapids, Kalamazoo, Lansing, Livonia, Rochester Hills, Southfield, Sterling Heights, Troy, Warren, Westland, and Wyoming. Each coefficient is from a separate regression. All regressions include fixed effects for city, claim year, claim month, birth year, and birth month. Robust standard errors are clustered at the city level. *** $\mathrm{p}<0.01, * *$ $\mathrm{p}<0.05, * \mathrm{p}<0.1$

Panel B: Changes in Per Capita ED Visits by Type

\begin{tabular}{|c|c|c|c|c|c|c|}
\hline & $\begin{array}{c}(1) \\
\text { Non- } \\
\text { Preventable }\end{array}$ & $\begin{array}{c}\text { (2) } \\
\text { Preventable }\end{array}$ & $\begin{array}{c}(3) \\
\text { Primary Care } \\
\text { Treatable }\end{array}$ & $\begin{array}{c}(4) \\
\text { Non- } \\
\text { Emergent }\end{array}$ & $\begin{array}{c}(5) \\
\text { PC } \\
\text { Sensitive }\end{array}$ & $\begin{array}{c}\text { (6) } \\
\text { Avoidable }\end{array}$ \\
\hline Flint*After & $\begin{array}{l}-0.0007 \\
(0.0010)\end{array}$ & $\begin{array}{l}-0.0033 \\
(0.0022)\end{array}$ & $\begin{array}{l}-0.0035 \\
(0.0041)\end{array}$ & $\begin{array}{l}-0.0051 \\
(0.0049)\end{array}$ & $\begin{array}{c}-0.0086 \\
(0.0090)\end{array}$ & $\begin{array}{l}-0.0118 \\
(0.0111)\end{array}$ \\
\hline $\begin{array}{l}\text { R-squared } \\
\text { Obs }\end{array}$ & $\begin{array}{c}0.005 \\
170150\end{array}$ & $\begin{array}{r}0.014 \\
170150\end{array}$ & $\begin{array}{c}0.021 \\
170150\end{array}$ & $\begin{array}{c}0.018 \\
170150\end{array}$ & $\begin{array}{c}0.026 \\
170150\end{array}$ & $\begin{array}{c}0.03 \\
170150\end{array}$ \\
\hline $\begin{array}{l}\text { Number of } \\
\text { Cities }\end{array}$ & 16 & 16 & 16 & 16 & 16 & 16 \\
\hline $\begin{array}{l}\text { Dependent } \\
\text { Variable Mean }\end{array}$ & 0.0123 & 0.0098 & 0.0427 & 0.0365 & 0.0793 & 0.0891 \\
\hline
\end{tabular}


Notes: Primary Care (PC) Sensitive visits include PC Treatable and Non-Emergent. Avoidable visits include Preventable, PC Treatable, and Non-Emergent. Regressions are at the at the enrollee-month level for all eligible, enrolled children. Treated city is Flint. Control cities are Ann Arbor, Dearborn, Detroit, Farmington Hills, Grand Rapids, Kalamazoo, Lansing, Livonia, Rochester Hills, Southfield, Sterling Heights, Troy, Warren, Westland, and Wyoming. Each coefficient is from a separate regression. All regressions include fixed effects for city, claim year, claim month, birth year, and birth month. Robust standard errors are clustered at the city level. ${ }^{* * *} \mathrm{p}<0.01, * * \mathrm{p}<0.05, * \mathrm{p}<0.1$ 
Table B3: Sample Limited to Children in Managed Care Plans

Panel A: Individual-Level Difference-in-Differences Results for all Enrolled Children

\begin{tabular}{lcccccc}
\hline & $\begin{array}{c}(1) \\
\text { Any lead } \\
\text { claims }\end{array}$ & $\begin{array}{c}\text { Any office } \\
\text { visit }\end{array}$ & $\begin{array}{c}(3) \\
\text { Any } \\
\text { vaccines }\end{array}$ & $\begin{array}{c}(4) \\
\text { Any ED } \\
\text { visit }\end{array}$ & $\begin{array}{c}(5) \\
\text { \# of } \\
\text { claims }\end{array}$ & $\begin{array}{c}\text { Total } \\
\text { payment }(\$)\end{array}$ \\
\hline Flint*After & $\begin{array}{c}0.035^{* * *} \\
(0.009)\end{array}$ & $\begin{array}{c}0.024^{* * *} \\
(0.008)\end{array}$ & $\begin{array}{c}0.015^{* *} \\
(0.006)\end{array}$ & $\begin{array}{c}-0.021^{* *} \\
(0.010)\end{array}$ & $\begin{array}{c}-0.05 \\
(0.094)\end{array}$ & $\begin{array}{c}13.503 \\
(18.065)\end{array}$ \\
R-squared & 0.027 & 0.103 & 0.044 & 0.042 & 0.029 & 0.074 \\
Obs. & 576,213 & 576,213 & 576,213 & 576,213 & 576,21 & 564,255 \\
$\begin{array}{l}\text { Number of Cities } \\
\text { Dependent }\end{array}$ & 16 & 16 & 16 & 16 & 16 & 16 \\
Variable Mean & 0.085 & 0.587 & 0.149 & 0.208 & 6.748 & 722.562 \\
\hline
\end{tabular}

Notes: Regressions are at the at the enrollee-month level for all eligible, enrolled children. Treated city is Flint. Control cities are Ann Arbor, Dearborn, Detroit, Farmington Hills, Grand Rapids, Kalamazoo, Lansing, Livonia, Rochester Hills, Southfield, Sterling Heights, Troy, Warren, Westland, and Wyoming. Each coefficient is from a separate regression. All regressions include fixed effects for city, claim year, claim month, birth year, and birth month. Robust standard errors are clustered at the city level. $* * * \mathrm{p}<0.01$, $* * \mathrm{p}<0.05, * \mathrm{p}<0.1$ 
Panel B: Changes in Per Capita ED Visits by Type

\begin{tabular}{|c|c|c|c|c|c|c|}
\hline & $\begin{array}{c}(1) \\
\text { Non- } \\
\text { Preventable }\end{array}$ & $\begin{array}{c}\text { (2) } \\
\text { Preventable }\end{array}$ & $\begin{array}{c}(3) \\
\text { Primary } \\
\text { Care } \\
\text { Treatable } \\
\end{array}$ & $\begin{array}{c}(4) \\
\text { Non- } \\
\text { Emergent }\end{array}$ & $\begin{array}{c}(5) \\
\text { PC } \\
\text { Sensitive }\end{array}$ & $\begin{array}{c}\text { (6) } \\
\text { Avoidable }\end{array}$ \\
\hline Flint*After & $\begin{array}{c}-0.0005 \\
(0.0003)\end{array}$ & $\begin{array}{c}-0.0053 * * \\
(0.0019)\end{array}$ & $\begin{array}{l}-0.0036 \\
(0.0024)\end{array}$ & $\begin{array}{c}-0.0078^{*} \\
(0.0042)\end{array}$ & $\begin{array}{c}-0.0114 * \\
(0.0065)\end{array}$ & $\begin{array}{c}-0.0167^{*} \\
(0.0084)\end{array}$ \\
\hline R-squared & 0.007 & 0.013 & 0.023 & 0.019 & 0.028 & 0.031 \\
\hline Obs. & 576,213 & 576,213 & 576,213 & 576,213 & 576,213 & 576,213 \\
\hline $\begin{array}{l}\text { Number of } \\
\text { Cities }\end{array}$ & 16 & 16 & 16 & 16 & 16 & 16 \\
\hline $\begin{array}{l}\text { Dependent } \\
\text { Variable } \\
\text { Mean }\end{array}$ & 0.0166 & 0.0161 & 0.0672 & 0.0565 & 0.1238 & 0.1399 \\
\hline
\end{tabular}

Notes: Primary Care (PC) Sensitive visits include PC Treatable and Non-Emergent. Avoidable visits include Preventable, PC Treatable, and Non-Emergent. Regressions are at the enrollee-month level for all eligible, enrolled children. Treated city is Flint. Control cities are Ann Arbor, Dearborn, Detroit, Farmington Hills, Grand Rapids, Kalamazoo, Lansing, Livonia, Rochester Hills, Southfield, Sterling Heights, Troy, Warren, Westland, and Wyoming. Each coefficient is from a separate regression. All regressions include fixed effects for city, claim year, claim month, birth year, and birth month. Robust standard errors are clustered at the city level. ${ }^{* * *} \mathrm{p}<0.01, * * \mathrm{p}<0.05, * \mathrm{p}<0.1$ 


\section{Appendix C: Alternative Treatment Starting Date}

Table C1: Treatment Starting in January 2016

Panel A: Individual-Level Difference-in-Differences Results for all Enrolled Children

\begin{tabular}{lcccccc}
\hline & $\begin{array}{c}(1) \\
\text { Any lead } \\
\text { claims }\end{array}$ & $\begin{array}{c}(2) \\
\text { Any office } \\
\text { visit }\end{array}$ & $\begin{array}{c}\text { Any } \\
\text { vaccines }\end{array}$ & $\begin{array}{c}\text { Any ED } \\
\text { visit }\end{array}$ & $\begin{array}{c}\text { \# of } \\
\text { claims }\end{array}$ & $\begin{array}{c}(6) \\
\text { Total } \\
\text { payment }(\$)\end{array}$ \\
\hline Flint*After Jan'16 & $\begin{array}{c}0.016^{* * *} \\
(0.002)\end{array}$ & -0.008 & 0.005 & $-0.007^{* * *}$ & 0.051 & 3.638 \\
& $(0.006)$ & $(0.003)$ & $(0.002)$ & $(0.035)$ & $(7.649)$ \\
R-squared & 0.004 & 0.074 & 0.028 & 0.012 & 0.042 & 0.059 \\
$\begin{array}{l}\text { Obs. } \\
\text { Number of Cities }\end{array}$ & 1618450 & 1618450 & 1618450 & 1618450 & 1618450 & 1602669 \\
$\begin{array}{l}\text { Dependent } \\
\text { Variable Mean }\end{array}$ & 16 & 16 & 16 & 16 & 16 & 16 \\
\hline
\end{tabular}

Notes: Regressions are at the enrollee-month level for all eligible, enrolled children. Treated city is Flint. Control cities are Ann Arbor, Dearborn, Detroit, Farmington Hills, Grand Rapids, Kalamazoo, Lansing, Livonia, Rochester Hills, Southfield, Sterling Heights, Troy, Warren, Westland, and Wyoming. Each coefficient is from a separate regression. All regressions include fixed effects for city, claim year, claim month, birth year, and birth month. Robust standard errors are clustered at the city level. ${ }^{* * *} \mathrm{p}<0.01,{ }^{* *}$ $\mathrm{p}<0.05, * \mathrm{p}<0.1$ 
Panel B: Changes in Per Capita ED Visits by Type

\begin{tabular}{lcccccc}
\hline & $\begin{array}{c}(1) \\
\text { Non- } \\
\text { Preventable }\end{array}$ & $\begin{array}{c}(2) \\
\text { Preventable }\end{array}$ & $\begin{array}{c}(3) \\
\text { Primary Care } \\
\text { Treatable }\end{array}$ & $\begin{array}{c}\text { Non- } \\
\text { Emergent }\end{array}$ & $\begin{array}{c}(5) \\
\text { PC } \\
\text { Sensitive }\end{array}$ & $\begin{array}{c}(6) \\
\text { Avoidable }\end{array}$ \\
\hline $\begin{array}{l}\text { Flint*After } \\
\text { Jan '16 }\end{array}$ & -0.0003 & $-0.0020^{* * *}$ & $-0.0020^{* *}$ & $-0.0023^{* * *}$ & $-0.0043^{* * *}$ & $-0.0063^{* * *}$ \\
& $(0.0002)$ & $(0.0002)$ & $(0.0007)$ & $(0.0006)$ & $(0.0009)$ & $(0.0009)$ \\
& 0.004 & 0.003 & 0.008 & 0.006 & 0.01 & 0.01 \\
$\begin{array}{l}\text { R-squared } \\
\begin{array}{l}\text { Obs. } \\
\text { Number of }\end{array}\end{array}$ & 1618450 & 1618450 & 1618450 & 1618450 & 1618450 & 1618450 \\
$\begin{array}{l}\text { Cities } \\
\text { Dependent }\end{array}$ & 16 & 16 & 16 & 16 & 16 & 16 \\
$\begin{array}{l}\text { Variable } \\
\text { Mean }\end{array}$ & 0.0072 & 0.0068 & 0.0284 & 0.024 & 0.0524 & 0.0592 \\
\hline
\end{tabular}

Notes: Primary Care (PC) Sensitive visits include PC Treatable and Non-Emergent. Avoidable visits include Preventable, PC Treatable, and Non-Emergent. Regressions are at the enrollee-month level for all eligible, enrolled children. Treated city is Flint. Control cities are Ann Arbor, Dearborn, Detroit, Farmington Hills, Grand Rapids, Kalamazoo, Lansing, Livonia, Rochester Hills, Southfield, Sterling Heights, Troy, Warren, Westland, and Wyoming. Each coefficient is from a separate regression. All regressions include fixed effects for city, claim year, claim month, birth year, and birth month. Robust standard errors are clustered at the city level. ${ }^{* * *} \mathrm{p}<0.01,{ }^{* *} \mathrm{p}<0.05,{ }^{*} \mathrm{p}<0.1$ 


\section{Appendix D: Fixed Birth Cohort}

Table D1: Following the Sample of Children Born Before April 2014

Panel A: Individual-Level Difference-in-Differences Results for all Enrolled Children

\begin{tabular}{lcccccc}
\hline & $\begin{array}{c}(1) \\
\text { Any lead } \\
\text { claims }\end{array}$ & $\begin{array}{c}(2) \\
\text { Any office } \\
\text { visit }\end{array}$ & $\begin{array}{c}\text { Any } \\
\text { vaccines }\end{array}$ & $\begin{array}{c}(4) \\
\text { Any ED } \\
\text { visit }\end{array}$ & $\begin{array}{c}(5) \\
\text { \# of } \\
\text { claims }\end{array}$ & $\begin{array}{c}\text { Total } \\
\text { payment (\$) }\end{array}$ \\
\hline Flint*After & $\begin{array}{c}0.030^{* * *} \\
(0.004)\end{array}$ & -0.012 & -0.003 & $-0.006^{* *}$ & $0.111^{* * *}$ & $6.486^{*}$ \\
& $(0.007)$ & $(0.004)$ & $(0.003)$ & $(0.035)$ & $(3.481)$ \\
R-squared & 0.007 & 0.075 & 0.028 & 0.013 & 0.05 & 0.08 \\
Obs. & 856217 & 856217 & 856217 & 856217 & 856217 & 849352 \\
Number of Cities & 16 & 16 & 16 & 16 & 16 & 16 \\
$\begin{array}{l}\text { Dependent } \\
\text { Variable Mean }\end{array}$ & 0.035 & 0.241 & 0.053 & 0.086 & 2.765 & 301.847 \\
\hline
\end{tabular}

Notes: Regressions are at the enrollee-month level for all eligible, enrolled children. Treated city is Flint. Control cities are Ann Arbor, Dearborn, Detroit, Farmington Hills, Grand Rapids, Kalamazoo, Lansing, Livonia, Rochester Hills, Southfield, Sterling Heights, Troy, Warren, Westland, and Wyoming. Each coefficient is from a separate regression. All regressions include fixed effects for city, claim year, claim month, birth year, and birth month. Robust standard errors are clustered at the city level. $* * * \mathrm{p}<0.01, * *$ $\mathrm{p}<0.05, * \mathrm{p}<0.1$ 
Panel B: Changes in Per Capita ED Visits by Type

\begin{tabular}{|c|c|c|c|c|c|c|}
\hline & $\begin{array}{c}(1) \\
\text { Non- } \\
\text { Preventable }\end{array}$ & $\begin{array}{c}(2) \\
\text { Preventable }\end{array}$ & $\begin{array}{c}(3) \\
\text { Primary Care } \\
\text { Treatable }\end{array}$ & $\begin{array}{c}(4) \\
\text { Non- } \\
\text { Emergent }\end{array}$ & $\begin{array}{c}(5) \\
\text { PC } \\
\text { Sensitive } \\
\end{array}$ & $\begin{array}{c}(6) \\
\text { Avoidable }\end{array}$ \\
\hline Flint*After & $\begin{array}{l}-0.0004 \\
(0.0005)\end{array}$ & $\begin{array}{c}-0.0026^{* * *} \\
(0.0001)\end{array}$ & $\begin{array}{c}-0.0046^{* *} \\
(0.0016)\end{array}$ & $\begin{array}{c}-0.0012 \\
(0.0008)\end{array}$ & $\begin{array}{c}-0.0058^{* *} \\
(0.0022)\end{array}$ & $\begin{array}{c}-0.0084 * * * \\
(0.0021)\end{array}$ \\
\hline R-squared & 0.005 & 0.003 & 0.009 & 0.007 & 0.01 & 0.011 \\
\hline Obs. & 856217 & 856217 & 856217 & 856217 & 856217 & 856217 \\
\hline Number of Cities & 16 & 16 & 16 & 16 & 16 & 16 \\
\hline $\begin{array}{l}\text { Dependent } \\
\text { Variable Mean }\end{array}$ & 0.0072 & 0.007 & 0.0273 & 0.0235 & 0.0509 & 0.0579 \\
\hline
\end{tabular}

Notes: Primary Care (PC) Sensitive visits include PC Treatable and Non-Emergent. Avoidable visits include Preventable, PC Treatable, and Non-Emergent. Regressions are at the enrollee-month level for all eligible, enrolled children. Treated city is Flint. Control cities are Ann Arbor, Dearborn, Detroit, Farmington Hills, Grand Rapids, Kalamazoo, Lansing, Livonia, Rochester Hills, Southfield, Sterling Heights, Troy, Warren, Westland, and Wyoming. Each coefficient is from a separate regression. All regressions include fixed effects for city, claim year, claim month, birth year, and birth month. Robust standard errors are clustered at the city level. ${ }^{* * *} \mathrm{p}<0.01,{ }^{* *} \mathrm{p}<0.05,{ }^{*} \mathrm{p}<0.1$ 


\section{Appendix E: Changes in Total Office Visits by Diagnosis Classification}

\section{Figure E1: Total Office Visits vs. Avoidable ED Visits}

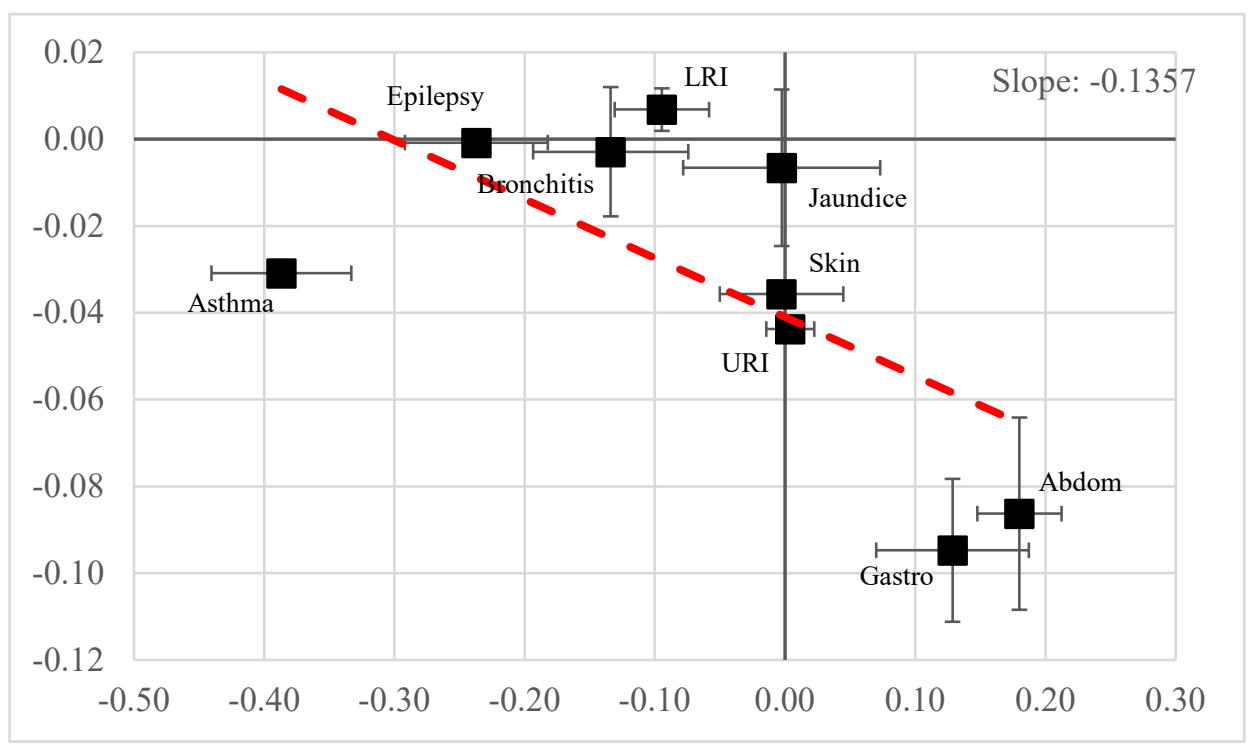

Notes: Each point is the estimate of a separate specification at the enrollee-month level for all children with claims in the specified CCS category. Treated city is Flint. Control cities are Ann Arbor, Dearborn, Detroit, Farmington Hills, Grand Rapids, Kalamazoo, Lansing, Livonia, Rochester Hills, Southfield, Sterling Heights, Troy, Warren, Westland, and Wyoming. All regressions include fixed effects for city, claim year, claim month, birth year, and birth month. Robust standard errors are clustered at the city level. Whiskers show a $95 \%$ confidence interval. 


\section{Appendix F: Pre-period Starting in May 2014 for ED Visits Type}

Table F1: Changes in Per Capita ED Visits by Type

\begin{tabular}{|c|c|c|c|c|c|c|}
\hline & $\begin{array}{c}\text { (1) } \\
\text { Non- } \\
\text { Preventable }\end{array}$ & Preventable & $\begin{array}{c}(3) \\
\text { Primary } \\
\text { Care } \\
\text { Treatable } \\
\end{array}$ & $\begin{array}{c}\text { (4) } \\
\text { Non- } \\
\text { Emergent }\end{array}$ & $\begin{array}{c}\text { (5) } \\
\text { PC } \\
\text { Sensitive }\end{array}$ & Avoidable \\
\hline Flint*After & $\begin{array}{l}-0.0001 \\
(0.0003)\end{array}$ & $\begin{array}{c}-0.0016 * * * \\
(0.0001)\end{array}$ & $\begin{array}{l}-0.0006 \\
(0.0008)\end{array}$ & $\begin{array}{c}-0.0016 * * * \\
(0.0005)\end{array}$ & $\begin{array}{c}-0.0022 * * \\
(0.0010)\end{array}$ & $\begin{array}{c}-0.0038 * * * \\
(0.0009)\end{array}$ \\
\hline R-squared & 0.004 & 0.003 & 0.009 & 0.006 & 0.01 & 0.01 \\
\hline Obs. & 1398971 & 1398971 & 1398971 & 1398971 & 1398971 & 1398971 \\
\hline $\begin{array}{l}\text { Number of } \\
\text { Cities }\end{array}$ & 16 & 16 & 16 & 16 & 16 & 16 \\
\hline $\begin{array}{l}\text { Dependent } \\
\text { Variable Mean }\end{array}$ & 0.0067 & 0.007 & 0.0282 & 0.0237 & 0.0519 & 0.059 \\
\hline
\end{tabular}

Notes: Primary Care (PC) Sensitive visits include PC Treatable and Non-Emergent. Avoidable visits include Preventable, PC Treatable, and Non-Emergent. Regressions are at the enrollee-month level for all eligible, enrolled children. Treated city is Flint. Control cities are Ann Arbor, Dearborn, Detroit, Farmington Hills, Grand Rapids, Kalamazoo, Lansing, Livonia, Rochester Hills, Southfield, Sterling Heights, Troy, Warren, Westland, and Wyoming. Each coefficient is from a separate regression. All regressions include fixed effects for city, claim year, claim month, birth year, and birth month. Robust standard errors are clustered at the city level. *** $\mathrm{p}<0.01, * * \mathrm{p}<0.05, * \mathrm{p}<0.1$ 


\section{Appendix G: Results with "Patched" NYU Algorithm}

Using the Johnston et al. (2017) classification of uncategorized visits, we re-estimated specification (1) for ED visits. Results are presented in Table G1; though the significance of most estimates is lost and the magnitudes are attenuated, the sign is consistent with our main results. We choose not to use this "patch" because the new classifications are not validated.

Table G1: Changes in Per Capita ED Visits by Type

\begin{tabular}{|c|c|c|c|c|c|c|}
\hline & $\begin{array}{c}(1) \\
\text { Non- } \\
\text { Preventable }\end{array}$ & $\begin{array}{c}\text { (2) } \\
\text { Preventable }\end{array}$ & $\begin{array}{c}(3) \\
\text { Primary } \\
\text { Care } \\
\text { Treatable } \\
\end{array}$ & $\begin{array}{c}\text { (4) } \\
\text { Non- } \\
\text { Emergent }\end{array}$ & $\begin{array}{c}\text { (5) } \\
\text { PC } \\
\text { Sensitive }\end{array}$ & $\begin{array}{c}(6) \\
\text { Avoidable }\end{array}$ \\
\hline Flint*After & $\begin{array}{c}0.0000 \\
(0.0005)\end{array}$ & $\begin{array}{c}-0.001 * * * \\
(0.0001)\end{array}$ & $\begin{array}{l}-0.0006 \\
(0.0009)\end{array}$ & $\begin{array}{l}-0.0006 \\
(0.0004)\end{array}$ & $\begin{array}{c}-0.0012 \\
(0.0013)\end{array}$ & $\begin{array}{l}-0.0022^{*} \\
(0.0012)\end{array}$ \\
\hline R-squared & 0.0051 & 0.0027 & 0.0079 & 0.0056 & 0.0089 & 0.0088 \\
\hline Obs. & $1,326,764$ & $1,326,764$ & $1,326,764$ & $1,326,764$ & $1,326,764$ & $1,326,764$ \\
\hline $\begin{array}{l}\text { Number of } \\
\text { enrollees }\end{array}$ & 67,167 & 67,167 & 67,167 & 67,167 & 67,167 & 67,167 \\
\hline Number of Cities & 16 & 16 & 16 & 16 & 16 & 16 \\
\hline $\begin{array}{l}\text { Dependent } \\
\text { Variable Mean }\end{array}$ & 0.0121 & 0.0072 & 0.037 & 0.029 & 0.066 & 0.0738 \\
\hline
\end{tabular}

Notes: Primary Care (PC) Sensitive visits include PC Treatable and Non-Emergent. Avoidable visits include Preventable, PC Treatable, and Non-Emergent. Regressions are at the enrollee-month level for all eligible, enrolled children. Treated city is Flint. Control cities are Ann Arbor, Dearborn, Detroit, Farmington Hills, Grand Rapids, Kalamazoo, Lansing, Livonia, Rochester Hills, Southfield, Sterling Heights, Troy, Warren, Westland, and Wyoming. Each coefficient is from a separate regression. All regressions include fixed effects for city, claim year, claim month, birth year, and birth month. Robust standard errors are clustered at the city level. $* * * \mathrm{p}<0.01, * * \mathrm{p}<0.05, * \mathrm{p}<0.1$ 


\section{Appendix H: Flexible Form Time Indicator}

Table H1: Flint Dummy Interacted with Multiple Dummies for Multiple Post-Periods

Panel A: Individual-Level Difference-in-Differences Results for all Enrolled Children

\begin{tabular}{|c|c|c|c|c|c|c|}
\hline & $\begin{array}{c}\text { (1) } \\
\text { Any lead } \\
\text { claims }\end{array}$ & $\begin{array}{c}\text { (2) } \\
\text { Any } \\
\text { office } \\
\text { visit } \\
\end{array}$ & $\begin{array}{c}(3) \\
\text { Any } \\
\text { vaccines }\end{array}$ & $\begin{array}{c}(4) \\
\text { Any ED } \\
\text { visit }\end{array}$ & $\begin{array}{c}\text { (5) } \\
\text { \# of claims }\end{array}$ & $\begin{array}{c}(6) \\
\text { Total } \\
\text { payment } \\
(\$)\end{array}$ \\
\hline Flint*Jan '15 & $\begin{array}{c}-0.0031 * * * \\
(0.0006)\end{array}$ & $\begin{array}{c}-0.0022 \\
(0.0061)\end{array}$ & $\begin{array}{c}-0.0016 \\
(0.0029)\end{array}$ & $\begin{array}{c}0.0015 \\
(0.0024)\end{array}$ & $\begin{array}{c}-0.1813 * * * \\
(0.0337)\end{array}$ & $\begin{array}{l}-22.66 \\
(13.29)\end{array}$ \\
\hline Flint*Sept '15 & $\begin{array}{c}0.0304 * * * \\
(0.0008)\end{array}$ & $\begin{array}{c}0.0104 \\
(0.0063)\end{array}$ & $\begin{array}{r}0.0070^{* *} \\
(0.0030)\end{array}$ & $\begin{array}{c}-0.0016 \\
(0.0022)\end{array}$ & $\begin{array}{c}0.0513 \\
(0.0429)\end{array}$ & $\begin{array}{l}42.86^{*} \\
(21.02)\end{array}$ \\
\hline $\mathrm{R}$-squared & 0.0072 & 0.0683 & 0.027 & 0.0098 & 0.041 & 0.0374 \\
\hline $\begin{array}{l}\text { F-Test } \\
\text { Obs. }\end{array}$ & $\begin{array}{c}1703.3 \\
1,330,177\end{array}$ & $\begin{array}{c}7.1 \\
1.330 .177\end{array}$ & $\begin{array}{c}15.8 \\
1.330 .177\end{array}$ & $\begin{array}{c}8.7 \\
1.330,177\end{array}$ & $\begin{array}{c}62.6 \\
1,330,177\end{array}$ & $\begin{array}{c}29.7 \\
1.330 .177\end{array}$ \\
\hline Number of Cities & 16 & 16 & 16 & 16 & 16 & 16 \\
\hline $\begin{array}{l}\text { Dependent } \\
\text { Variable Mean }\end{array}$ & 0.0328 & 0.0266 & 0.0685 & 0.091 & 3.336 & 630.191 \\
\hline
\end{tabular}

Notes: Flint*Jan '15 indicates enrollee-month observations in Flint between January and August 2015. Flint ${ }^{*}$ Sept ' 15 indicates enrollee-month observations in Flint between September 2015 and December 2016. F-statistic of joint significance of DiD coefficients is reported. Regressions are at the enrollee-month level for all eligible, enrolled children. Treated city is Flint. Control cities are Ann Arbor, Dearborn, Detroit, Farmington Hills, Grand Rapids, Kalamazoo, Lansing, Livonia, Rochester Hills, Southfield, Sterling Heights, Troy, Warren, Westland, and Wyoming. Each coefficient is from a separate regression. All regressions include fixed effects for city, claim year, claim month, birth year, and birth month. Robust standard errors are clustered at the city level. $* * * \mathrm{p}<0.01, * * \mathrm{p}<0.05, * \mathrm{p}<0.1$ 
Panel B: Changes in Per Capita ED Visits by Type

\begin{tabular}{|c|c|c|c|c|c|c|}
\hline & $\begin{array}{c}(1) \\
\text { Non- } \\
\text { Preventable }\end{array}$ & Preventable & $\begin{array}{c}(3) \\
\text { Primary } \\
\text { Care } \\
\text { Treatable } \\
\end{array}$ & $\begin{array}{c}(4) \\
\text { Non- } \\
\text { Emergent }\end{array}$ & $\begin{array}{c}\text { (5) } \\
\text { PC } \\
\text { Sensitive }\end{array}$ & $\begin{array}{c}\text { (6) } \\
\text { Avoidable }\end{array}$ \\
\hline Flint*Jan '15 & $\begin{array}{c}0.0005^{* *} \\
(0.0001)\end{array}$ & $\begin{array}{c}-0.0005 \\
(0.0003)\end{array}$ & $\begin{array}{l}-0.0029 \\
(0.0018\end{array}$ & $\begin{array}{c}0.0023 * * * \\
(0.0004)\end{array}$ & $\begin{array}{c}-0.0006 \\
(0.0023)\end{array}$ & $\begin{array}{l}-0.0012 \\
(0.0026)\end{array}$ \\
\hline Flint*Sept '15 & $\begin{array}{c}0.0004 \\
(0.0003)\end{array}$ & $\begin{array}{c}-0.0015^{* * *} \\
(0.0001)\end{array}$ & $\begin{array}{l}-0.0022 \\
(0.0016)\end{array}$ & $\begin{array}{c}-0.0001 \\
(0.0004)\end{array}$ & $\begin{array}{c}-0.0023 \\
(0.0017)\end{array}$ & $\begin{array}{c}-0.0039^{* *} \\
(0.0017)\end{array}$ \\
\hline R-squared & 0.004 & 0.003 & 0.0068 & 0.0052 & 0.008 & 0.0082 \\
\hline F-Test & 9.04 & 48.81 & 1.58 & 13.79 & 6.84 & 19.59 \\
\hline Obs. & $1,330,177$ & $1,330,177$ & $1,330,177$ & $1,330,177$ & $1,330,177$ & $1,330,177$ \\
\hline Number of Cities & 16 & 16 & 16 & 16 & 16 & 16 \\
\hline $\begin{array}{l}\text { Dependent } \\
\text { Variable Mean }\end{array}$ & 0.0077 & 0.0067 & 0.0295 & 0.0248 & 0.0544 & 0.0611 \\
\hline
\end{tabular}

Notes: Flint*Jan '15 indicates enrollee-month observations in Flint between January and August 2015. Flint ${ }^{*}$ Sept ' 15 indicates enrollee-month observations in Flint between September 2015 and December 2016. F-statistic of joint significance of DiD coefficients is reported. Dependent variables: Primary Care (PC) Sensitive visits include PC Treatable and Non-Emergent. Avoidable visits include Preventable, PC Treatable, and Non-Emergent. Regressions are at the enrollee-month level for all eligible, enrolled children. Treated city is Flint. Control cities are Ann Arbor, Dearborn, Detroit, Farmington Hills, Grand Rapids, Kalamazoo, Lansing, Livonia, Rochester Hills, Southfield, Sterling Heights, Troy, Warren, Westland, and Wyoming. Each coefficient is from a separate regression. All regressions include fixed effects for city, claim year, claim month, birth year, and birth month. Robust standard errors are clustered at the city level. $* * * \mathrm{p}<0.01, * * \mathrm{p}<0.05, * \mathrm{p}<0.1$ 


\section{Appendix I: Patient Characteristics for Lead Tests}

Table I1: Characteristics of Patients Receiving a Lead Test

\begin{tabular}{|c|c|c|c|c|c|}
\hline & \multicolumn{2}{|c|}{ Before } & \multicolumn{2}{|c|}{ After } & \multirow{2}{*}{$\begin{array}{c}\text { Difference- } \\
\text { in- } \\
\text { Differences }\end{array}$} \\
\hline & Flint & Other & Flint & Other & \\
\hline Female & 0.493 & 0.476 & 0.502 & 0.466 & 0.018 \\
\hline Black & 0.559 & 0.339 & 0.545 & 0.352 & -0.027 \\
\hline \multirow[t]{2}{*}{ Maternal Age } & 24.766 & 26.842 & 25.067 & 27.32 & -0.177 \\
\hline & $(5.456)$ & $(5.797)$ & $(5.186)$ & $(5.715)$ & \\
\hline Claims & 1300 & 9511 & 56549 & 9063 & \\
\hline
\end{tabular}

Note: $* * * \mathrm{p}<0.01,{ }^{* *} \mathrm{p}<0.05, * \mathrm{p}<0.1$ Standard deviation in parentheses for non-dummy variables. Other cities are Ann Arbor, Dearborn, Detroit, Farmington Hills, Grand Rapids, Kalamazoo, Lansing, Livonia, Rochester Hills, Southfield, Sterling Heights, Troy, Warren, Westland, and Wyoming. All regressions control for female, maternal race and education, and include fixed effects for city, month, year, birth year, and birth month. Robust standard errors are clustered at the city level. 


\section{Appendix J: Lead Testing in the ED}

While testing for blood lead level is possible in the ED, it is done so on suspicion of lead poisoning in anticipation of inpatient admission. Treatment for exposure to high levels of lead, warranting hospital admission, is chelation therapy. Our data does not include any claims for chelation therapy. Thus, we feel confident that admissions on suspected lead exposure did not occur in Flint during the period covered by our data.

Subacute lead exposure among children presents with nonspecific symptoms that may only involve irritability, difficulty concentrating, and fatigue. Most commonly, it is associated with constipation. Beyond admission, the recommended best practice for suspected exposure to lead is to remove the source of contamination, test for lead in an outpatient setting, and follow up with a primary care provider. For a child brought by their parent to the ED on suspicion of lead poisoning, the providers may ascertain that the child is in no immediate danger and take a blood sample to send to an off-campus testing facility with results sent to a primary care provider for follow up. Alternatively, the provider may ascertain that the child is in no immediate danger and refer the parent to primary care for testing.

In an informal survey, 13 emergency physicians were asked: "A parent brings their child to the ED requesting a lead test. The child has no specific symptoms, maybe a mild rash or mild abdominal pain. No apparent urgency. Which would you do?" The responses were distributed as follows:

Order lead test in the ED: 2

Refer to primary care: 6

Test and follow up with primary care: 5

Therefore, we conclude that parents requesting a blood lead test for their child in the ED setting would be referred to primary care.

Reference:

Williams S. Heavy Metals and Iron Overdose. In: Mattu A and Swadron S, ed. CorePendium. Burbank, CA: CorePendium, LLC. https://www.emrap.org/corependium/chapter/recGL1d1CsAmcMhdL/Heavy-Metals-andIron-Overdose. Updated November 7, 2019. Accessed November 7, 2019. 


\section{Appendix K: Alternative Control Groups}

Table K1: Cities with Highest Rates of Children with Elevated Blood Lead Levels in Michigan: More than 1,000 Children Tested

Panel A: Individual-Level Difference-in-Differences Results for all Enrolled Children

\begin{tabular}{lcccccc} 
& $\begin{array}{c}(1) \\
\text { Any lead } \\
\text { claims }\end{array}$ & $\begin{array}{c}\text { Any office } \\
\text { visit }\end{array}$ & $\begin{array}{c}\text { Any } \\
\text { vaccines }\end{array}$ & $\begin{array}{c}\text { Any ED } \\
\text { visit }\end{array}$ & $\begin{array}{c}(5) \\
\text { \# of } \\
\text { claims }\end{array}$ & $\begin{array}{c}\text { Total } \\
\text { payment (\$) }\end{array}$ \\
\hline Flint*After & $\begin{array}{c}0.015^{* * *} \\
(0.001)\end{array}$ & $\begin{array}{c}-0.007 \\
(0.005)\end{array}$ & $\begin{array}{c}0.0001 \\
(0.003)\end{array}$ & $\begin{array}{c}-0.001 \\
(0.001)\end{array}$ & $\begin{array}{c}0.126^{* *} \\
(0.039)\end{array}$ & $\begin{array}{c}22.066 \\
(12.054)\end{array}$ \\
$\begin{array}{l}\text { R-squared } \\
\text { Obs. }\end{array}$ & 0.005 & 0.062 & 0.023 & 0.009 & 0.043 & 0.059 \\
$\begin{array}{l}\text { Number of Cities } \\
\text { Dependent }\end{array}$ & $1,379,219$ & $1,379,219$ & $1,379,219$ & $1,379,219$ & $1,379,219$ & $1,364,489$ \\
Variable Mean & 0.036 & 0.227 & 0.054 & 0.096 & 3.084 & 356.483 \\
\hline
\end{tabular}

Notes: Regressions are at the enrollee-month level for all eligible, enrolled children. Treated city is Flint. Control cities are Detroit, Grand Rapids, Kalamazoo, Lansing, Wyoming, Battle Creek, Port Huron, Hamtramck, and Saginaw (Urban 2018). Each coefficient is from a separate regression. All regressions include fixed effects for city, claim year, claim month, birth year, and birth month. Total payment is trimmed to exclude the top $1 \%$. Robust standard errors are clustered at the city level.

$* * * \mathrm{p}<0.01, * * \mathrm{p}<0.05, * \mathrm{p}<0.1$ 
Panel B: Changes in Per Capita ED Visits by Type

\begin{tabular}{lcccccc}
\hline & $(1)$ & $(2)$ & $(3)$ & $(4)$ & $(5)$ & $(6)$ \\
& $\begin{array}{c}\text { Non- } \\
\text { Preventable }\end{array}$ & Preventable & $\begin{array}{c}\text { Primary } \\
\text { Care } \\
\text { Treatable }\end{array}$ & $\begin{array}{c}\text { Non- } \\
\text { Emergent }\end{array}$ & $\begin{array}{c}\text { PC } \\
\text { Sensitive }\end{array}$ & Avoidable \\
\hline Flint*After & 0.0003 & $-0.002^{* * *}$ & -0.001 & -0.0004 & $-0.002^{* * *}$ & $-0.004^{* * *}$ \\
& $(0.0002)$ & $(0.0001)$ & $(0.001)$ & $(0.001)$ & $(0.0004)$ & $(0.0005)$ \\
& 0.005 & 0.002 & 0.007 & 0.005 & 0.008 & 0.008 \\
R-squared & $1,379,219$ & $1,379,219$ & $1,379,219$ & $1,379,219$ & $1,379,219$ & $1,379,219$ \\
$\begin{array}{l}\text { Obs. } \\
\text { Number of Cities }\end{array}$ & 11 & 11 & 11 & 11 & 11 & 11 \\
$\begin{array}{l}\text { Dependent } \\
\text { Variable Mean }\end{array}$ & 0.008 & 0.007 & 0.031 & 0.026 & 0.058 & 0.065 \\
\hline
\end{tabular}

Notes: Regressions are at the enrollee-month level for all eligible, enrolled children. Treated city is Flint. Control cities are Detroit, Grand Rapids, Kalamazoo, Lansing, Wyoming, Battle Creek, Port Huron, Hamtramck, and Saginaw (Urban, 2018). Each coefficient is from a separate regression. All regressions include fixed effects for city, claim year, claim month, birth year, and birth month. Total payment is trimmed to exclude the top $1 \%$. Robust standard errors are clustered at the city level.

$* * * \mathrm{p}<0.01, * * \mathrm{p}<0.05, * \mathrm{p}<0.1$ 
Table K2: Main Sample Including Pontiac and Muskegon

Panel A: Individual-Level Difference-in-Differences Results for all Enrolled Children

\begin{tabular}{lcccccc} 
& $\begin{array}{c}(1) \\
\text { Any lead } \\
\text { claims }\end{array}$ & $\begin{array}{c}\text { Any office } \\
\text { visit }\end{array}$ & $\begin{array}{c}\text { Any } \\
\text { vaccines }\end{array}$ & $\begin{array}{c}\text { Any ED } \\
\text { visit }\end{array}$ & $\begin{array}{c}(5) \\
\text { \# of } \\
\text { claims }\end{array}$ & $\begin{array}{c}\text { Total } \\
\text { payment (\$) }\end{array}$ \\
\hline Flint*After & $\begin{array}{c}0.017^{* * *} \\
(0.001)\end{array}$ & $\begin{array}{c}-0.003 \\
(0.006)\end{array}$ & $\begin{array}{c}0.005^{*} \\
(0.003)\end{array}$ & $\begin{array}{c}-0.004^{* *} \\
(0.002)\end{array}$ & $\begin{array}{c}0.087^{* * *} \\
(0.029)\end{array}$ & $\begin{array}{c}11.221^{*} \\
(6.120)\end{array}$ \\
$\begin{array}{l}\text { R-squared } \\
\text { Obs. }\end{array}$ & 0.004 & 0.073 & 0.027 & 0.012 & 0.042 & 0.059 \\
$\begin{array}{l}\text { Number of Cities } \\
\text { Dependent }\end{array}$ & $1,738,325$ & $1,738,325$ & $1,738,325$ & $1,738,325$ & $1,738,325$ & $1,721,319$ \\
Variable Mean & 0.035 & 0.251 & 0.063 & 0.089 & 3.091 & 349.352 \\
\hline
\end{tabular}

Notes: Regressions are at the enrollee-month level for all eligible, enrolled children. Treated city is Flint. Control cities are Ann Arbor, Dearborn, Detroit, Farmington Hills, Grand Rapids, Kalamazoo, Lansing, Livonia, Rochester Hills, Southfield, Sterling Heights, Troy, Warren, Westland, Wyoming, Pontiac, and Muskegon. Each coefficient is from a separate regression. All regressions include fixed effects for city, claim year, claim month, birth year, and birth month. Total payment is trimmed to exclude the top $1 \%$. Robust standard errors are clustered at the city level.

$* * * \mathrm{p}<0.01, * * \mathrm{p}<0.05, * \mathrm{p}<0.1$ 
Panel B: Changes in Per Capita ED Visits by Type

\begin{tabular}{|c|c|c|c|c|c|c|}
\hline & $\begin{array}{c}(1) \\
\text { Non- } \\
\text { Preventable }\end{array}$ & Preventable & $\begin{array}{c}(3) \\
\text { Primary } \\
\text { Care } \\
\text { Treatable }\end{array}$ & $\begin{array}{c}(4) \\
\text { Non- } \\
\text { Emergent }\end{array}$ & $\begin{array}{c}(5) \\
\text { PC } \\
\text { Sensitive }\end{array}$ & $\begin{array}{c}\text { (6) } \\
\text { Avoidable }\end{array}$ \\
\hline Flint*After & $\begin{array}{l}-0.00002 \\
(0.0003)\end{array}$ & $\begin{array}{c}-0.002 * * * \\
(0.0002)\end{array}$ & $\begin{array}{l}-0.002 * \\
(0.001)\end{array}$ & $\begin{array}{l}-0.001 * * \\
(0.0004)\end{array}$ & $\begin{array}{c}-0.003 * * \\
(0.001)\end{array}$ & $\begin{array}{c}-0.005 * * * \\
(0.001)\end{array}$ \\
\hline R-squared & 0.004 & 0.003 & 0.008 & 0.006 & 0.009 & 0.009 \\
\hline Obs. & $1,738,325$ & $1,738,325$ & $1,738,325$ & $1,738,325$ & $1,738,325$ & $1,738,325$ \\
\hline Number of Cities & 18 & 18 & 18 & 18 & 18 & 18 \\
\hline $\begin{array}{l}\text { Dependent } \\
\text { Variable Mean }\end{array}$ & 0.007 & 0.007 & 0.028 & 0.024 & 0.053 & 0.059 \\
\hline
\end{tabular}

Notes: Regressions are at the enrollee-month level for all eligible, enrolled children. Treated city is Flint. Control cities are Ann Arbor, Dearborn, Detroit, Farmington Hills, Grand Rapids, Kalamazoo, Lansing, Livonia, Rochester Hills, Southfield, Sterling Heights, Troy, Warren, Westland, Wyoming, Pontiac, and Muskegon. Each coefficient is from a separate regression. All regressions include fixed effects for city, claim year, claim month, birth year, and birth month. Total payment is trimmed to exclude the top $1 \%$. Robust standard errors are clustered at the city level.

$* * * \mathrm{p}<0.01, * * \mathrm{p}<0.05, * \mathrm{p}<0.1$ 


\section{Appendix L: Weekday vs. Weekend effects}

Table L1: Results Restricted to Only Weekday Visits

Panel A: Individual-Level Difference-in-Differences Results for all Enrolled Children

\begin{tabular}{|c|c|c|c|c|c|c|}
\hline & (1) & (2) & (3) & (4) & (5) & (6) \\
\hline & Lead Claims & Office Visits & Vaccines & ED Visits & Claims & Payment \\
\hline \multicolumn{7}{|l|}{ Panel A: Any } \\
\hline Flint*After & $\begin{array}{c}0.017 * * * \\
(0.001)\end{array}$ & $\begin{array}{l}-0.005 \\
(0.006)\end{array}$ & $\begin{array}{c}0.004 \\
(0.003)\end{array}$ & $\begin{array}{l}-0.002 \\
(0.001)\end{array}$ & $\begin{array}{c}0.015 * * * \\
(0.004)\end{array}$ & $\begin{array}{c}0.014 * * * \\
(0.004)\end{array}$ \\
\hline \multirow{2}{*}{$\begin{array}{l}\text { R-squared } \\
\text { Dependent } \\
\text { Variable Mean }\end{array}$} & 0.004 & 0.071 & 0.027 & 0.009 & 0.088 & 0.088 \\
\hline & 0.034 & 0.243 & 0.063 & 0.065 & 0.436 & 0.435 \\
\hline \multicolumn{7}{|c|}{ Panel B: Number per Capita } \\
\hline Flint*After & $\begin{array}{c}0.017 * * * \\
(0.001)\end{array}$ & $\begin{array}{l}-0.039 \\
(0.034)\end{array}$ & $\begin{array}{c}0.013 * * * \\
(0.004)\end{array}$ & $\begin{array}{l}0.0020 \\
(0.002)\end{array}$ & $\begin{array}{c}0.043 \\
(0.026)\end{array}$ & $\begin{array}{c}16.39 \\
(13.203)\end{array}$ \\
\hline R-squared & 0.004 & 0.044 & 0.018 & 0.006 & 0.038 & 0.026 \\
\hline $\begin{array}{l}\text { Dependent } \\
\text { Variable Mean }\end{array}$ & 0.038 & 1.024 & 0.082 & 0.097 & 2.714 & 435.966 \\
\hline Obs. & $1,621,164$ & $1,621,164$ & $1,621,164$ & $1,621,164$ & $1,621,164$ & $1,621,164$ \\
\hline Number of Cities & 16 & 16 & 16 & 16 & 16 & 16 \\
\hline
\end{tabular}

Notes: Regressions are at the enrollee-month level for all eligible, enrolled children. Treated city is Flint. Control cities are Ann Arbor, Dearborn, Detroit, Farmington Hills, Grand Rapids, Kalamazoo, Lansing, Livonia, Rochester Hills, Southfield, Sterling Heights, Troy, Warren, Westland, Wyoming. Each coefficient is from a separate regression. All regressions include fixed effects for city, claim year, claim month, birth year, and birth month. Total payment is trimmed to exclude the top 1\%. Robust standard errors are clustered at the city level.

$* * * \mathrm{p}<0.01, * * \mathrm{p}<0.05, * \mathrm{p}<0.1$ 
Panel B: Changes in Per Capita ED Visits by Type

\begin{tabular}{lcccccc}
\hline & $\begin{array}{c}(1) \\
\text { Non- } \\
\text { Preventable }\end{array}$ & $\begin{array}{c}(2) \\
\text { Preventable }\end{array}$ & $\begin{array}{c}(3) \\
\text { Primary Care } \\
\text { Treatable }\end{array}$ & $\begin{array}{c}(4) \\
\text { Non- } \\
\text { Emergent }\end{array}$ & $\begin{array}{c}\text { PC } \\
\text { Sensitive }\end{array}$ & $\begin{array}{c}\text { Avoidable } \\
\text { Flint*After }\end{array}$ \\
& 0.0002 & $-0.001^{* * *}$ & $-0.002^{* *}$ & $-0.001^{* * *}$ & $-0.002^{* * *}$ & $-0.004^{* * *}$ \\
& $(0.0002)$ & $(0.0002)$ & $(0.001)$ & $(0.0002)$ & $(0.001)$ & $(0.001)$ \\
R-squared & 0.003 & 0.002 & 0.006 & 0.005 & 0.008 & 0.009 \\
Obs. & $1,621,164$ & $1,621,164$ & $1,621,164$ & $1,621,164$ & $1,621,164$ & $1,621,164$ \\
Number of Cities & 16 & 16 & 16 & 16 & 16 & 16 \\
$\begin{array}{l}\text { Dependent } \\
\text { Variable Mean }\end{array}$ & 0.005 & 0.005 & 0.02 & 0.017 & 0.037 & 0.049 \\
\hline
\end{tabular}

Notes: Regressions are at the enrollee-month level for all eligible, enrolled children. Treated city is Flint. Control cities are Ann Arbor, Dearborn, Detroit, Farmington Hills, Grand Rapids, Kalamazoo, Lansing, Livonia, Rochester Hills, Southfield, Sterling Heights, Troy, Warren, Westland, Wyoming. Each coefficient is from a separate regression. All regressions include fixed effects for city, claim year, claim month, birth year, and birth month. Total payment is trimmed to exclude the top $1 \%$. Robust standard errors are clustered at the city level.

$* * * \mathrm{p}<0.01, * * \mathrm{p}<0.05, * \mathrm{p}<0.1$ 
Table L2: Results Restricted to Only Weekend Visits

Panel A: Individual-Level Difference-in-Differences Results for all Enrolled Children

\begin{tabular}{|c|c|c|c|c|c|c|}
\hline & $\begin{array}{c}\text { (1) } \\
\text { Lead } \\
\text { Claims }\end{array}$ & $\begin{array}{c}\text { (2) } \\
\text { Office } \\
\text { Visits }\end{array}$ & $\begin{array}{c}\text { (3) } \\
\text { Vaccines }\end{array}$ & $\begin{array}{c}\text { (4) } \\
\text { ED Visits }\end{array}$ & $\begin{array}{c}\text { (5) } \\
\text { Claims }\end{array}$ & $\begin{array}{c}\text { (6) } \\
\text { Payment }\end{array}$ \\
\hline $\begin{array}{l}\text { Panel A: Any } \\
\text { Flint*After }\end{array}$ & $\begin{array}{c}0.0001 \\
(0.0001)\end{array}$ & $\begin{array}{l}0.003 * * * \\
(0.001)\end{array}$ & $\begin{array}{c}0.0004 * * * \\
(0.0001)\end{array}$ & $\begin{array}{c}-0.002 * * * \\
(0.001)\end{array}$ & $\begin{array}{c}0.004 \\
(0.003)\end{array}$ & $\begin{array}{c}0.004 \\
(0.003)\end{array}$ \\
\hline $\begin{array}{l}\text { R-squared } \\
\text { Dependent Variable Mean }\end{array}$ & $\begin{array}{c}0.0005 \\
0.001 \\
\end{array}$ & $\begin{array}{l}0.016 \\
0.011\end{array}$ & $\begin{array}{l}0.001 \\
0.001\end{array}$ & $\begin{array}{l}0.003 \\
0.029\end{array}$ & $\begin{array}{l}0.019 \\
0.073\end{array}$ & $\begin{array}{l}0.019 \\
0.073\end{array}$ \\
\hline $\begin{array}{l}\text { Panel B: Number per Capit } \\
\text { Flint*After }\end{array}$ & $\begin{array}{c}0.0001 \\
(0.0001)\end{array}$ & $\begin{array}{c}0.013 * * * \\
(0.004)\end{array}$ & $\begin{array}{l}0.001 * * * \\
(0.0001)\end{array}$ & $\begin{array}{c}-0.002 * * \\
(0.001)\end{array}$ & $\begin{array}{c}0.023 \\
(0.014)\end{array}$ & $\begin{array}{c}20.216 * * \\
(7.437)\end{array}$ \\
\hline $\begin{array}{l}\text { R-squared } \\
\text { Dependent Variable Mean }\end{array}$ & $\begin{array}{c}0.0004 \\
0.001\end{array}$ & $\begin{array}{l}0.006 \\
0.033\end{array}$ & $\begin{array}{l}0.001 \\
0.002\end{array}$ & $\begin{array}{c}0.002 \\
0.04\end{array}$ & $\begin{array}{l}0.006 \\
0.348\end{array}$ & $\begin{array}{c}0.008 \\
115.428 \\
\end{array}$ \\
\hline $\begin{array}{l}\text { Obs. } \\
\text { Number of Cities }\end{array}$ & $\begin{array}{c}1,621,164 \\
16\end{array}$ & $\begin{array}{c}1,621,164 \\
16\end{array}$ & $\begin{array}{c}1,621,164 \\
16\end{array}$ & $\begin{array}{c}1,621,164 \\
16\end{array}$ & $\begin{array}{c}1,621,164 \\
16\end{array}$ & $\begin{array}{c}1,621,164 \\
16\end{array}$ \\
\hline
\end{tabular}

Notes: Regressions are at the enrollee-month level for all eligible, enrolled children. Treated city is Flint. Control cities are Ann Arbor, Dearborn, Detroit, Farmington Hills, Grand Rapids, Kalamazoo, Lansing, Livonia, Rochester Hills, Southfield, Sterling Heights, Troy, Warren, Westland, Wyoming. Each coefficient is from a separate regression. All regressions include fixed effects for city, claim year, claim month, birth year, and birth month. Total payment is trimmed to exclude the top 1\%. Robust standard errors are clustered at the city level.

$* * * \mathrm{p}<0.01, * * \mathrm{p}<0.05, * \mathrm{p}<0.1$ 
Panel B: Changes in Per Capita ED Visits by Type

\begin{tabular}{|c|c|c|c|c|c|c|}
\hline & $\begin{array}{c}(1) \\
\text { Non- } \\
\text { Preventable }\end{array}$ & $\begin{array}{c}\text { (2) } \\
\text { Preventable }\end{array}$ & $\begin{array}{c}(3) \\
\text { Primary } \\
\text { Care } \\
\text { Treatable } \\
\end{array}$ & $\begin{array}{c}\text { (4) } \\
\text { Non- } \\
\text { Emergent }\end{array}$ & $\begin{array}{c}(5) \\
\text { PC } \\
\text { Sensitive }\end{array}$ & $\begin{array}{c}\text { (6) } \\
\text { Avoidable }\end{array}$ \\
\hline Flint*After & $\begin{array}{c}-0.0002 * * \\
(0.0001)\end{array}$ & $\begin{array}{c}-0.001 * * * \\
(0.0001)\end{array}$ & $\begin{array}{c}-0.0003 \\
(0.0002)\end{array}$ & $\begin{array}{l}-0.0003 \\
(0.0002)\end{array}$ & $\begin{array}{c}-0.0007^{*} \\
(0.0003)\end{array}$ & $\begin{array}{c}-0.002 * * * \\
(0.001)\end{array}$ \\
\hline R-squared & 0.001 & 0.001 & 0.002 & 0.002 & 0.003 & 0.007 \\
\hline Obs. & $1,621,164$ & $1,621,164$ & $1,621,164$ & $1,621,164$ & $1,621,164$ & $1,621,164$ \\
\hline Number of Cities & 16 & 16 & 16 & 16 & 16 & 16 \\
\hline $\begin{array}{l}\text { Dependent Variable } \\
\text { Mean }\end{array}$ & 0.002 & 0.002 & 0.008 & 0.007 & 0.015 & 0.034 \\
\hline
\end{tabular}

Notes: Regressions are at the enrollee-month level for all eligible, enrolled children. Treated city is Flint. Control cities are Ann Arbor, Dearborn, Detroit, Farmington Hills, Grand Rapids, Kalamazoo, Lansing, Livonia, Rochester Hills, Southfield, Sterling Heights, Troy, Warren, Westland, Wyoming. Each coefficient is from a separate regression. All regressions include fixed effects for city, claim year, claim month, birth year, and birth month. Total payment is trimmed to exclude the top $1 \%$. Robust standard errors are clustered at the city level.

$* * * \mathrm{p}<0.01, * * \mathrm{p}<0.05, * \mathrm{p}<0.1$ 


\section{Appendix M: Randomized Inference}

Figure M1: Average treatment effect of random assignment of treatment city

Panel A: Any Lead

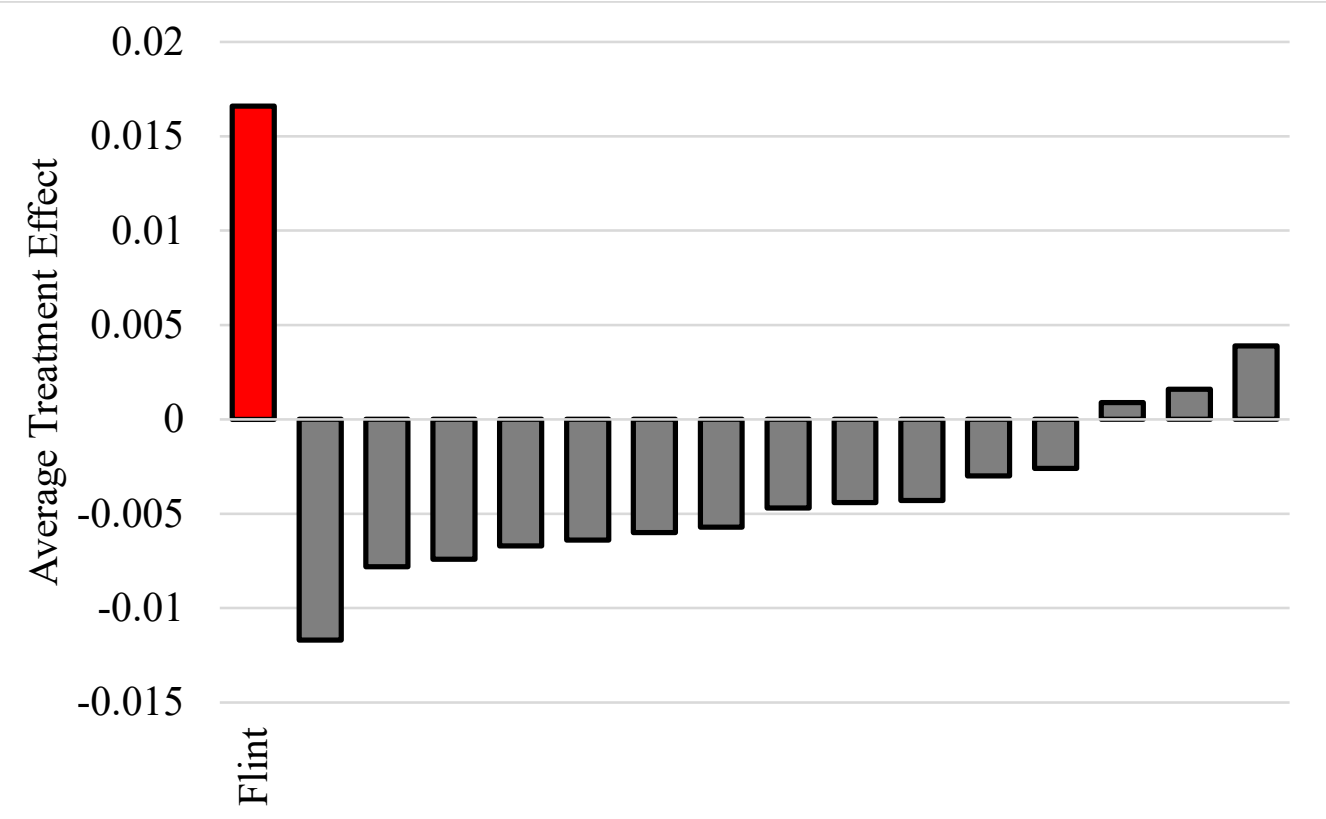

Comparison Cities 
Panel B: Avoidable Visits

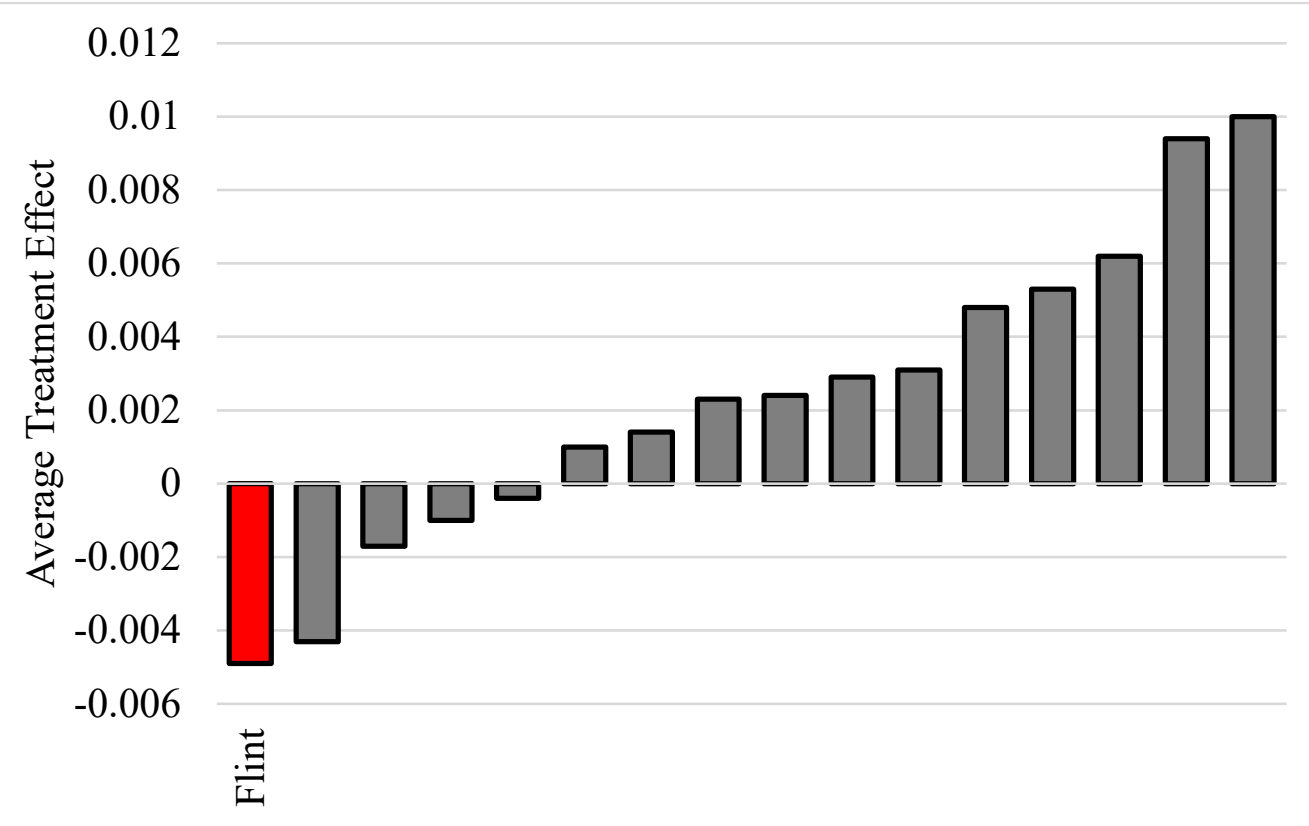

Comparison Cities 
Panel C: Non-Preventable Visits

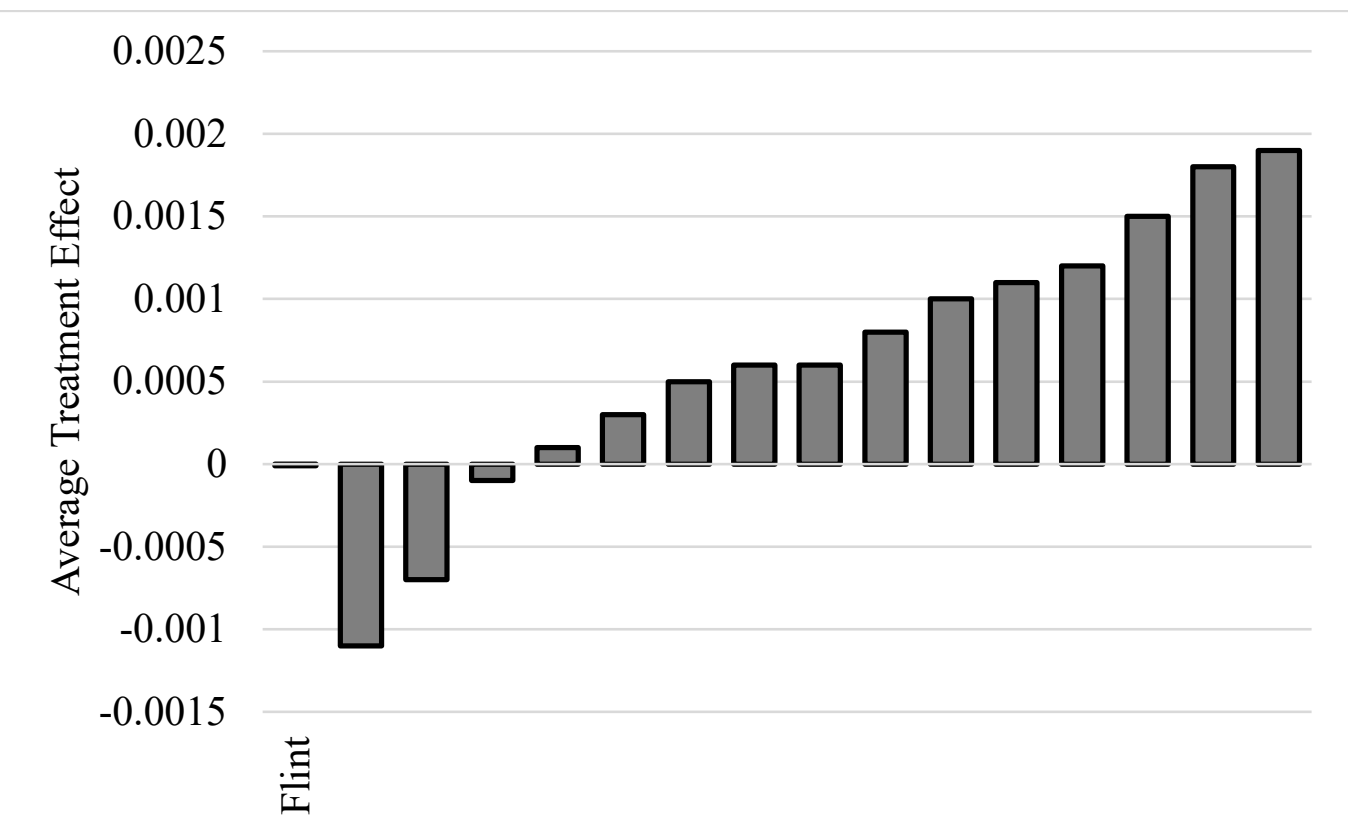

Comparison Cities 


\begin{tabular}{|c|c|c|c|}
\hline & (1) & (2) & (3) \\
\hline & $\begin{array}{c}\text { Any Office } \\
\text { Visits }\end{array}$ & $\begin{array}{l}\text { Avoidable ED } \\
\text { Visits }\end{array}$ & Any Lead \\
\hline Flint*After Qtr 1 & $\begin{array}{l}0.008 * \\
(0.004)\end{array}$ & $\begin{array}{c}0.002 \\
(0.002)\end{array}$ & $\begin{array}{c}0.013 * * * \\
(0.001)\end{array}$ \\
\hline Flint*After Qtr 2 & $\begin{array}{c}0.026 * * * \\
(0.004)\end{array}$ & $\begin{array}{c}-0.004 * * * \\
(0.001)\end{array}$ & $\begin{array}{c}0.084 * * * \\
(0.001)\end{array}$ \\
\hline Flint*After Qtr 3 & $\begin{array}{l}-0.001 \\
(0.006)\end{array}$ & $\begin{array}{c}-0.006 * * * \\
(0.001)\end{array}$ & $\begin{array}{c}0.006 * * * \\
(0.001)\end{array}$ \\
\hline Flint*After Qtr 4 & $\begin{array}{c}-0.025 * * \\
(0.010)\end{array}$ & $\begin{array}{c}-0.010 * * * \\
(0.002)\end{array}$ & $\begin{array}{c}-0.012 * * * \\
(0.003)\end{array}$ \\
\hline Flint*After Qtr 5 & $\begin{array}{c}-0.033 * * * \\
(0.007)\end{array}$ & $\begin{array}{c}-0.004 * * * \\
(0.001)\end{array}$ & $\begin{array}{c}-0.007 * * \\
(0.002)\end{array}$ \\
\hline Flint*After Qtr 6 & $\begin{array}{c}-0.028 * * * \\
(0.007)\end{array}$ & $\begin{array}{c}-0.014 * * * \\
(0.002)\end{array}$ & $\begin{array}{c}-0.012 * * \\
(0.004)\end{array}$ \\
\hline Flint*After Qtr 7 & $\begin{array}{c}-0.042 * * * \\
(0.010)\end{array}$ & $\begin{array}{c}-0.013 * * * \\
(0.002)\end{array}$ & $\begin{array}{c}-0.013 * * \\
(0.005)\end{array}$ \\
\hline Flint*After Qtr 8 & $\begin{array}{c}-0.037 * * \\
(0.013)\end{array}$ & $\begin{array}{c}-0.014 * * * \\
(0.004)\end{array}$ & $\begin{array}{l}-0.005 \\
(0.006)\end{array}$ \\
\hline Flint*After Qtr 9 & $\begin{array}{c}-0.033^{* * *} \\
(0.008)\end{array}$ & $\begin{array}{c}-0.019 * * * \\
(0.002)\end{array}$ & $\begin{array}{c}-0.004 \\
(0.003)\end{array}$ \\
\hline R-squared & 0.065 & 0.011 & 0.004 \\
\hline Dependent Variable Mean & 0.231 & 0.054 & 0.034 \\
\hline Obs. & $2,207,819$ & $2,207,819$ & $2,207,819$ \\
\hline Number of Cities & 16 & 16 & 16 \\
\hline
\end{tabular}

Notes: Avoidable visits include Preventable, PC Treatable, and Non-Emergent. Regressions are at the enrollee-month level for all eligible, enrolled children. Treated city is Flint. Control cities are Ann Arbor, Dearborn, Detroit, Farmington Hills, Grand Rapids, Kalamazoo, Lansing, Livonia, Rochester Hills, Southfield, Sterling Heights, Troy, Warren, Westland, and Wyoming. Each column is from a separate regression. All regressions include fixed effects for city, claim year, claim month, birth year, and birth month. Robust standard errors are clustered at the city level. $* * * p<0.01, * * p<0.05, * p<0.1$ 